\title{
Boşanmış ve Evli Ebeveynlere Sahip Ergenlerin Beş Boyutlu İyi Oluş Modeli ve İnternet Bağımlılık Düzeylerinin İncelenmesi
}

DOI: 10.26466/opus.650135

\author{
Besra Taş ${ }^{*}$ - Sedat Ateş **
}

* Dr. Öğr. Üyesi,Sabahattin Zaim Üniversitesi, Eğitim Fakültesi, İstanbul / Türkiye

E-Posta: besra.tas@izu.edu.tr

ORCID: 0000-0002-1273-4429

** Psk. Dan., Sabahattin Zaim Üniversitesi, Eğitim Fakültesi, İstanbul / Türkiye

E-Posta: atessedat17@hotmail.com

ORCID: 0000-0003-0835-9782

Öz

$\mathrm{B} u$ araştırmanın amacı boşanmış ve evli ebeveynlere sahip ergenlerde beş boyutlu iyi oluş modeli ve internet bağımlılık düzeyleri arasında bir ilişki olup olmadığım saptamaktır. Araştırmanın grubu İstanbul ilinde 2018-2019 eğitim-öğretim yılında lisede öğrenim gören 102 boşanmış ve 109 boşanmamış aileye sahip toplam 211 öğrenci oluşturmaktadır. Araştırma sonuçlarına göre ergenlerin iyi oluş özelliklerinin ebeveyni boşanmış ve ebeveyni evli ergenlere göre incelenmiş, iyi oluş düzeyi ebeveyninin boşanmış veya evli olmasına göre bir değişiklik göstermediği sonucu elde edilmiştir. Ebeveyni boşanmış ergenlerin yetişmiş olduğu ebeveyn eğitim tutumuna bakıldığında demokratik, otoriter ve aşırı koruyucu ailede yetişen ergenlerin ihmalkâr ailede yetişen ergenlerden daha yüksek olduğu sonucu elde edilmiştir. Sonuç olarak ihmalkâr ailelerde yetişen ergenlerin iyi oluş düzeyleri diğer eğitim tutumlarında yetişenlere göre daha düşük olduğu sonucu elde edilmiştir. İnternet bağımlılığı puanları incelendiğinde ebeveyni boşanmış ergenlerin ebeveyni evli ergenlere göre biraz daha yüksek ortalamaya sahip olduğu ama bu farkın istatistiki olarak anlamlı olmadığı görülmektedir. Sonuç olarak internet bağımlılığı düzeyi ebeveyninin boşanmış veya ebeveyni evli olmasına göre bir değişiklik göstermemektedir. Araştırma sonucuna göre her iki grup ergenlerde internet kullanma süresi 5 saat ve üzerine yaklaştıkça internet bağımlılığının arttı̆̆ı bulgusu elde edilmiş̧ir. Bunun yanında yüksek sürelerde internet kullanımının internet bağımlılığını arttırdığı sonucu elde edilmiştir.

Anahtar Kelimeler: İnternet Bă̆ımlılı̆̆ı, İyi Oluş, Ergenler, Ebeveyn Boşanması 


\title{
Five Dimensional Well-Being Model of Adolescents with Divorced and Non-Divorced Parents and Examination of Internet Addiction Levels
}

\begin{abstract}
The aim of this study is to determine whether there is a relationship or not between five-dimensional well-being model and internet addiction levels in adolescents with divorced and married parents.

The group of the research consists of 211 students with 102 divorced and 109 non-divorced families studying in high school students in the 2018-2019 academic year in Istanbul.According to the results of the research, well-being characteristics of adolescents examined between divorced and non-divorced parents. It was concluded that the level of well-being did not change according to whether her parents were divorced or married.Considering the parental education attitude raised by adolescents whose parents are divorced.It was concluded that the adolescents raised in the democratic, authoritarian and overprotective family were higher than the adolescents raised in the negligent family. As a result, it was concluded that the well-being levels of adolescents raised in negligent families were lower than those raised in other educational attitudes. When internet addiction scores are examined, it is seen that adolescents whose parents are divorced have a slightly higher average compared to married adolescents, but this difference is not statistically significant. As a result, the level of internet addiction does not differ depending on whether parents are divorced or non-divorcedAccording to the results of the study, the finding that internet addiction increases when the internet usage time is 5 hours or more in both groups of adolescents.In addition, it has been concluded that high internet usage increases internet addiction.
\end{abstract}

Keywords: Internet Addiction, Well-Being, Adolescents, Divorcement of Parents 


\section{Günümüzde İnternet Kullanımı}

Bu alanda yapılan çalışmalarda Günüç (2013); Göldağ (2017); Kayri ve Günüç (2016); Çevik ve Çelikkaleli (2010), ergenlerin internet kullanımı ile ilgili sorunlar yaşadıkları ve bağımlılık durumu olduğu belirtilmektedir. Günüç (2013) yapmış olduğu çalışmasında ergenlerin internet kullanım sürelerinin artmasıyla birlikte bağımlı olma puanlarının da arttı̆̆ bulgusu elde edilmiştir. Yine aynı çalışmada interneti kullanım amacının bağımlılık açısından önemli bir faktör olduğu; internette araştırma yapma, iş amaçlı ve haber okuma gibi sebeplerden ötürü kullanılan internetin bağımlılığa neden olmadığı belirtilmiştir. Kayri ve Günüç (2016) yapmış olduğu çalışmasında sosyoekonomik düzeyi (SED) yüksek olan ailelerde ergenlerin internet bağımlısı olma olasılıklarının daha yüksek olduğu belirtilmiştir. Çevik ve Çelikkaleli (2010) yapmış oldukları çalışmada anne-baba tutumlarının internet bağımlılığ olarak algıladığı durumlarda internet bağımlılığı puanlarının diğer annebaba tutumlarına göre anlamlı seviyede yüksek olduğu belirtilmiştir. Başka bir çalışmada, anne-babası boşanmış olan ergenlerin ebeveynleriyle ayrı ayrı nitelikli vakit geçirdikleri takdirde internet bağımlılık düzeylerinin daha az olabileceği belirtilmektedir (Demirli ve Arslan, 2018). Derin ve Bilge (2016), internete daha çok evden bağlanan ergenlerin cep telefonuyla ve internet kafeden bağlananlara oranla internet bağımlılı̆̆ı riskinin daha düşük olduğunu belirtmektedir.

\section{İnternet Bağımlıı̆̆ı ve Beş Boyutlu İyi Oluş}

Sarriera ve arkadaşları (2013) yaptıkları araştırmada ergenlerin boş zamanlarında ailesiyle birlikte vakit geçirme ve ailesine yakın olmasının ergenlerde öznel iyi oluşu önemli ölçüde etkilediği belirtilmektedir. Söner ve Yılmaz (2018) çalışmalarına göre liseli öğrencilerin psikolojik iyi oluş düzeylerinin cinsiyete göre farklılaşmamaktadır. Orta ve geç ergenlik dönemindeki bireylerle yapılan bir araştırmada erkeklerin psikolojik iyi oluş düzeylerinin kızlardan daha yüksektir (Sagone ve Caroli, 2014). Yine aynı araştırmada geç ergenlik döneminde olanların psikolojik iyi oluş düzeylerinin orta ergenlik döneminde olanlardan nispeten daha yüksek olduğu belirtilmektedir. Seligmanın (2011) (PERMA), çok boyutlu iyi oluş modeli, PERMA, mutluluk, haz 
neşe ve rahatlık gibi olumlu duygular üzerine durmaktadır. Seligman (2011) kuramının beş harflerle aldığı PERMA (İngilizce kavramların baş harfleri alınmıştır) ifadesi ile beş bileşen üzerine inşa etmiştir. Bu beş bilişen olan PERMA'nın açılımı, 1. Olumlu duygular (positive emotions), 2. bağlanma (engagement), 3. olumlu ilişkiler (positive relationships), 4. anlam (meaning) ve 5. başarı (accomplishment) olarak açıklanmakta.

Birinci bilişen olan, "olumlu duygular" (positive emotions), olumlu duyguları merkeze almakta. Olumlu duygular bireyin farkındalığını artırmakla birlikte daha çok bir olumlu zihin yarattığı belirtilmekte. Şüphesiz, umut, onur, sevinç ve sevgi gibi olumlu duygular iyi olmayı pekiştirmekte. Olumlu duygular bireyin bireysel kaynaklar inşa etmeye yönelterek düşünce-eylem repertuvarını genişlettiğini belirtmekte (Streit (2014, s. 75ff.)

İyi oluş kuramın ikinci bilişeni olan, "bağlanma" (engagement), burada kişinin kendini tamamen yaptığı işe vermesi vurgulanmakta. Kendi seçtikleri hedeflere yüksek bir içsel motivasyonla hedefine konsantre ile odaklanmak, bundan haz, mutluluk duymak ve kendini tamamen o hedefe vermek olarak tanımlanmakta. Kendini tüm benliği ile tamamen yaptığı iş veya etkinliğe vermesi, bir ahenk içerisinde olup mutlu olmak.

Üçüncü bilişen olan "olumlu ilişkiler" (positive relationships), İnsanın iyi olması olumlu iyi ilişkileri olması ile ilişkili olduğu belirtilmekte. İnsanlarla iletişimde olan bireylerin daha güvende yaşadıkları vurgulanmakta. Seligman, En son hangi şaka üzerine güldünüz?, En son ne zaman tarif edilmeyecek şekilde mutluluk hissettiniz?, Ne zaman tarifi olmayacak şekilde memnun oldunuz?, gibi sorular genelde sorarak, tüm bunların insanlarla olan ilişkilerde yaşanıldığını açıklamakta.

Seligman (2011) Sartre'ın "cehennem başkalarıdır" sözünü eleştirerek insanların, üzüntülü zamanların en etkili ilacı ve en güvenilir dayanağı insan olduğunu belirtmektedir. Tüm bu doğrultuda iyi olmak için iyi ilişkilere ihtiyaç olduğu ortaya çıkmakta. Diğer insanlar olumlu iyi olmanın insan psikolojisine iyi geldiği vurgulanmakta. Buda özellikle ergenlerde iyi insan ilişkileri olmaları tam ergenlerin ve genç yetişkinlerin ihtiyaç duydukları şeydir.

Dördüncü bileşen olan, "anlam" (meaning), Seligman'in (2011) anlam kavramını, bireyin kendinden daha büyük bir şeye aidiyet hissetmesi ve ona hizmet etme arzusu duyması olarak açıklamakta. En zor ergenlerin bile, ken- 
dinden daha büyük bir şeye anlam yükleyip, topluluğa aidiyet hissettiklerinde uyum sağlandığı ve kendilerini olumlu yönde motive ettiği görünmekte.

Beşinci bilişen olan, başarı (accomplishment)'de gerek nesnel olarak elde edilen başarıda bahsedilmemekte, örneğin, bunu yaparsam, sonra, bu olacak şeklinde değil, daha çok, bunu yaşadım, buna ulaştım gibi durumları içermekte. Bireyin başarıya ulaşma isteği, amaca ulaşma hissiyatının yaşaması ve bununla olumlu duyguyu hissetmesi (Streit (2014, s. 75). Derin ve Bilge (2016) yapmış oldukları araştırmada ergenlerde pozitif duygular azaldıkça internet bağımlılığı olma ihtimalinin arttığı sonucu elde edilmiştir. Ayrıca ergenlerde yaşam doyumu ile internet bağımlılığı arasında pozitif bir ilişki olduğu belirtilmektedir. Meslek yüksekokulunda iyilik halleri ile internet bağımlılığı arasındaki ilişkiyi inceleyen başka bir araştırmada ise bu iki değişken arasında negatif bir ilişki olduğu belirtilmektedir (Çiğdem ve Yarar, 2015). Hindistan' da üniversite öğrencilerinde yapılan bir çalışmada ise internet bağımlılığı ile psikolojik iyi oluş arasında negatif bir ilişki olduğu saptanmıştır (Sharma ve Sharma, 2018). Çin'de yapılan bir araştırmaya göre internet bağımlılığının ergenlerde psikolojik iyi oluşu azaltmaktadır (Wang ve ark., 2013). Ergenlerle yapılan başka bir araştırmada ise internette online geçirilen zaman ile psikolojik iyi oluş arasında anlamlı bir ilişki bulunamadığı belirtilmektedir (Gross, Juvonen ve Gable, 2002). Sezer (2011) ortaöğretim düzeyindeki öğrenciler üzerinde yaptığı araştırmaya göre boş vakitlerini spor yaparak değerlendiren öğrencilerin normal lise ve meslek lisesine oranla öznel iyi oluşu daha yüksektir. Baş, Soysal ve Aysan (2016) yaptıkları araştırmaya göre üniversite öğrencilerinin psikolojik iyi oluş düzeyleri azaldıkça internetin sorunlu kullanımı ve negatif sonuçları artmaktadır. Yu ve Shek (2018) ergenler üzerinde yapmış oldukları çalışmalarında öznel iyi oluşu artırmak için bireydeki internet bağımlılığının takip edilmesine ve azaltılmasına yönelik stratejilerin dikkate alınmasının gerekliliğini belirtmektedir. Bunun dışında ergen bireyin kendi online etkinliklerinin günlük kaydını yapmasına yardımcı olunabilmesi, internetin doğru kullanımı, zaman yönetimi ve hedef belirleme becerilerinin kazandırılmasının etkili olabileceği belirtilmektedir. 


\section{Ebeveyn Boşanması ve Ergenler}

Demirli ve Arslan (2018) lise öğrencilerinin bağımlılık düzeylerini ölçmeyi amaçladıkları çalışmalarında ebeveynleri boşanmış ergenlerin internet bağımlılıklarının yaş değişkenine ve baba eğitim durumu değişkenine göre farklılaşmadığını belirtmektedirler. Yine aynı çalışmaya göre ebeveynleri boşanmış ergenlerden 0-30 dakika ve 61-90 dakika internette vakit harcayanların internet bağımlılıkları kontrol güçlüğü seviyesinde iken ebeveynleri boşanmamış ergenlerden 31-60 dakika internette vakit harcayanların internet bağımlılıkları kontrol güçlüğü ve işlevselde bozulma seviyelerindedir. Tas (2019) yapmış olduğu çalışmasında ergenlerin okula bağlanma ve oyun bağımlılı̆̆ı düzeylerinin ergenlerin ebeveyninin boşanmış veya evli olmasına göre değişmediği sonucu elde edilmiştir. Çalışmada oyun bağımlılı̆̆ında 5 saat ve üzeri internet kullanan genel ergen grubunun oyun bağımlılığı puanları sırasıyla 1,2,3,4 saat kullananlara göre anlamlı bir şekilde daha yüksektir. Ergenlerin interneti kullanma saati 5 saat ve üzerine çıktığında oyun bağımlılıklarının da artmakta olduğu tespit edilmiştir. Alanın uzmanları olan, Wallerstein ve Blakeslee (1989), Dreikurs (1968), Fthenakıs, Niesel ve Kunze, (1982) çalışmaları incelendiğinde boşanma süreci ve sonrasını yaşayan bireyler için, hem yetişkinler hem de çocuklar/ergenler üzerinde oldukça zor bir geçiş ve yardım alınması gereken bir süreç olarak belirtmektedirler. Tas (2017), (2018), boşanma sonrası süreçte ebeveynlerin çocuğa/ergene karşı duruşu ve vereceği desteğin düzeyi çocukların ve ergenlerin hangi derecede olumlu/olumsuz etkilendiklerini belirlemektedir. Schmidt-Denter ve Beelmann (1995), uzun süre yapmış olduğu bireyler, çocuklar ve ergenler boşanma yardım grup danışmanlığında, bu danışmanlığın bireyler üzerinde oldukça olumlu sonuçlar doğurduğunu, özellikle boşanma sonrası ebeveyn ile çocuk iletişimi, kardeşler arasındaki iletişimi, davranış bozukluğunun düzelmesi, boşanma sonrası rahatsızlıklarının giderilmesi, boşanma sonrası yeni sürece adapte olma, topluma entegre olma alanlarında başarıya ulaşıldığını belirtmektedir (Schmidt-Denter ve Beelmann, 1995, s. 358). 


\section{Yöntem}

\section{Araştırma Modeli}

$\mathrm{Bu}$ araştırma ailesi birlikte yaşayan ve boşanmış lise öğrencilerinin internet bağımlılığı ve iyi oluş düzeylerini incelemeyi amaçlayan tarama modelinde ilişkisel bir çalışmadır (Creswell, 2012). Çalışmada nicel veri toplama yöntemleri kullanılmıştır. Ailesi birlikte yaşayan ve boşanmış lise öğrencilerinin internet bağımlılığı ve iyi oluş düzeyleri çeşitli demografik değişkenlere göre incelenmiştir.

\section{Araştırma Soruları}

1. Ebeveyni boşanmış ve ebeveynleri evli ergenlerin Beş Boyutlu İyi Oluş Modeli ve İnternet Bağımlılık Düzeyleri arasında anlamlı fark var mıdır?

2. Ebeveyni boşanmış ve ebeveynleri evli ergenlerin Beş Boyutlu İyi Oluş Modeli ve İnternet Bağımlılık Düzeyleri; cinsiyete, ebeveynlerin medeni durumuna, yaşa, günlük internet kullanımına, öğrenim gördüğü okul türüne, şu an yaşadığı ekonomik duruma ve yetişmiş olduğu ebeveyn eğitim tutumune göre anlamlı şekilde farklılaşmakta mıdır?

\section{Çalışma Grubu}

Çalışmaya İstanbul ilinde 2018-2019 eğitim-öğretim yılında lisede öğrenim gören 102 boşanmış ve 109 boşanmamış aileye sahip toplam 211 öğrenci katılmıştır. Katılımcıların yaş ortalaması 15.5, standart sapması 1.2, katılımcların 74'ünün erkek, 137'sinin ise kız olduğu tespit edilmiştir. Çalışma grubuna ilişkin detaylı bilgiler tablo 1 ve 2' de gösterilmiştir. Buna göre ebeveynin medeni durumu ile cinsiyete göre dağılımı tablo 1'de ve ebeveynin medeni durumu ile yaşa göre dağılım ise tablo 2 'de gösterilmiştir.

Tablo 1. Ebeveynin medeni durumu ve cinsiyete göre dağılımı

\begin{tabular}{lllll}
\hline Ebeveyn medeni durumu & Cinsiyet & Frekans & Yüzde & Toplam yüzde \\
\hline Evli & Erkek & 27 & 24.771 & 24.771 \\
& Kız & 82 & 75.229 & 100 \\
& Toplam & $\mathbf{1 0 9}$ & $\mathbf{1 0 0}$ & \\
\hline Boşanmış & Erkek & 47 & 46.078 & 46.078 \\
& Kiz & 55 & 53.922 & 100 \\
& Toplam & $\mathbf{1 0 2}$ & $\mathbf{1 0 0}$ & \\
\hline
\end{tabular}


Tablo 2. Ebeveynin medeni durumu ve yaşa göre dağılımı

\begin{tabular}{lllll}
\hline Ebeveyn medeni durumu & Yaş & Frekans & Yüzde & Toplam yüzde \\
\hline Evli & 14 & 41 & 37.615 & 37.963 \\
& 15 & 26 & 23.853 & 62.037 \\
& 16 & 25 & 22.936 & 85.185 \\
& 17 & 14 & 12.844 & 98.148 \\
& 18 & 2 & 1.835 & 100 \\
\hline Boşanmıs & Toplam & $\mathbf{1 0 9}$ & $\mathbf{1 0 0}$ & \\
& 14 & 18 & 17.647 & 17.647 \\
& 15 & 23 & 22.549 & 40.196 \\
& 16 & 31 & 30.392 & 70.588 \\
& 17 & 25 & 24.510 & 95.098 \\
& 18 & 5 & 4.902 & 100 \\
\hline
\end{tabular}

\section{Veri Toplama Araçları}

ЕРОСН Ölçeği: Kern, Benson, Steinberg ve Steinberg (2016) tarafından geliştirilen EPOCH Ölçeği ergenlerde iyi oluşu ölçmektedir. 20 maddeden oluşan ölçme aracı 5'li likert tipi bir ölçektir (1: Hiçbir zaman - 5: Her zaman). Alınabilecek en düşük puan 20, en yüksek puan 100 olup yüksek puan yüksek iyi oluşa işaret etmektedir. Ölçek 5 alt boyuttan oluşmaktadır (Bağlılık, Kararlılık, İyimserlik, İlişkililik, Mutluluk). Ölçek ayrıca toplam iyi oluş puanını vermektedir. Ölçeğin Türkçe geçerlik ve güvenirlik çalışmaları Demirci ve Ekşi (2015) tarafından yapılmış olup ölçeğin geçerli ve güvenilir olduğu belirtilmektedir. EPOCH ölçeğinin Cronbach Alpha iç tutarlılık katsayısının ölçeğin toplam puanı için .95 olduğu belirtilmektedir.

Young İnternet Bağımlılı̆̆ı Testi Kısa Formu (YiBT-KF): Young (1998) tarafından geliştirilen Pawlikowski ve arkadaşları (2013) tarafından kısa forma dönüştürülen ölçeğin Türkçe uyarlaması Kutlu ve arkadaşları (2016) tarafından yapılmıştır. 12 maddeden oluşan ölçme aracı 5'li likert tipi bir ölçektir (1: Hiçbir zaman - 5: Çok sık). Geçerlilik ve güvenirlilik çalışmaları Kutlu ve arkadaşları (2013) tarafından yapılan ölçek hem ergenlerde hem de üniversitede okuyan öğrencilerde geçerli ve güvenilir olarak belirtilmektedir. YİBTKF güvenirlik çalışmasında Cronbach Alpha katsayısı ergenlerde .86, üniversite öğrencilerinde .91 olduğu belirtilmektedir. Ölçekte ters puanlamalı soru bulunmamaktadır ve ölçekten alınan puan arttıkça internet bağımlılık düzeyinin de arttığını göstermektedir. 


\section{Verilerin Toplanması ve Analizi}

Analizlerde gruplar arası varyans analizleri (ANOVA) ve t testi kullanılmıştır. Parametrik analizler kullanıldığ 1 için değişkenlerin dağılımları incelenmiş çarpıklık ve basıklık değerlerinin sırasıyla iyi oluş için (0.4-0.03), internet bağımlılığı için (0.5-0.02) olduğu tespit edilmiş ve dağılımın normal olduğu sonucuna varılmıştır. Varyans analizleri için varyansların eşteş olup olmadığ levene testi ile kontrol edilmiş ve tüm analizleri için varyansların eşteş olduğu görülmüştür.

\section{Bulgular}

$\mathrm{Bu}$ araştırmada ilk önce ebeveyni boşanmış ve ebeveyni evli bireylerin iyi oluş ve internet bağımlılığının cinsiyet, ebeveyni boşanmış ve evli olması, yaş, yetiştiği eğitim stili, günlük internet kullanımı ve sosyo-ekonomik durum gibi değişkenlere göre farklılaşıp farklılaşmadığı karşılaştırılmıştır. Daha sonra ebeveyni boşanmış ergenlerin iyi oluş ve internet bağımlılı̆̆ düzeylerinin cinsiyete; yaşa, öğrenim gördüğü okul türüne, şu an yaşadığı ekonomik duruma ve yetişmiş olduğu ebeveyn eğitim tutumune ve günlük internet kullanımına göre farklılaşıp farklılaşmadığı ortaya konmuştur. Son olarak ebeveyni evli bireylerin iyi oluş ve internet bağımlılığı düzeylerinin cinsiyete, yaşa, öğrenim gördüğü okul türüne, şu an yaşadığı ekonomik duruma, yetişmiş olduğu ebeveyn eğitim tutumune ve günlük internet kullanımına göre arasındaki farklar incelenmiştir. Analizlere geçmeden önce değişkenlere ilişkin betimsel istatistikler tablo 3'te sunulmuştur.

Tablo 3. Değişkenlerin cinsiyete ve ebeveyn medeni durumuna göre dağılımlan

\begin{tabular}{lllllllll}
\hline & \multicolumn{2}{c}{ İnternet bağımlılı̆̆ } & \multicolumn{2}{c}{ İyi Oluş } & \multicolumn{3}{c}{ İnternet bağımlılı̆̆ } & \multicolumn{2}{c}{ İyi Oluş } \\
\cline { 2 - 8 } & Erkek & Kız & Erkek & Kiz & Evli & Boşanmış & Evli & Boşanmış \\
\hline Geçerli kişi sayısı & 74 & 137 & 74 & 137 & 109 & 102 & 109 & 102 \\
Ortalama & 29.29 & 28.83 & 67.98 & 68.27 & 28.51 & 29.51 & 69.77 & 66.47 \\
Standart sapma & 10.2 & 9.21 & 14.49 & 13.95 & 9.16 & 10.0 & 13.96 & 14.14 \\
En düşük değer & 1 & 12 & 27 & 30 & 12 & 12 & 27 & 30 \\
En yüksek değer & 6 & 56 & 9 & 95 & 6 & 51 & 9 & 95 \\
\%25 dilim & 21 & 22 & 59.000 & 59 & 22 & 21.7 & 60.5 & 5 \\
\%50 dilim & 30 & 27 & 69.000 & 7 & 27 & 30 & 71 & 66.5 \\
\%75 dilim & 36.2 & 35. & 77.250 & 78.5 & 34 & 37 & 80 & 77 \\
\hline
\end{tabular}


Ebeveyni Boşanmış ve Ebeveyni Evli Ergenlerin İyi Oluş Düzeylerinin Ebeveyni boşanmış ve ebeveyni evli olması, Cinsiyet, Öğrenim Gördüğ̈̈ Okul Türü, Yaş, Yetiştiği Ĕ̆itim Stili, Sosyoekonomik Duruma ve Günlük İnternet Kullanımına Göre İncelenmesine İlişkin Bulgular

Araştırmada öğrencilerin iyi oluş özelliklerinin ebeveyni boşanmış ve ebeveyni evli ergenlere göre incelenmesi amaçlanmıştır. Bu amaç doğrultusunda yapılan $\mathrm{t}$ testi sonuçları tablo 4 'te sunulmuştur. tablo 4 'te görüleceği üzere iyi oluş puanları incelendiğinde ebeveyni evli ergenlerin ebeveyni boşanmış ergenlere göre biraz daha yüksek ortalamaya sahip olduğu ama bu farkın istatistiki olarak anlamlı olmadığ görülmektedir $t(209)=1.70, p=0.09$. Sonuç olarak iyi oluş düzeyi ebeveyninin boşanmış veya evli olmasına göre bir değişiklik göstermemektedir.

Tablo 4. İyi oluş düzeyleri ebeveyni boşanmış ve ebeveyni evli ergenlere göre karşılaştırlmasina ilişkin t test tablosu (Levene: İyi Olus 0.6)

\begin{tabular}{lllllllll}
\hline Group & $\mathbf{N}$ & Mean & SD & SE & T & df & p & Cohen's d \\
\hline Evli & 109 & 69.77 & 13.9 & 1.33 & 1.70 & 209 & 0.09 & 0.23 \\
Boşanmış & 102 & 66.47 & 14.1 & 1.40 & & & & \\
\hline
\end{tabular}

Araştırmada ergenlerin iyi oluş düzeylerinde erkek ve kızlar arasında anlamlı farkın olup olmadığı incelenmek istenmiş ve bu analize ilişkin bağımsız örneklem $\mathrm{t}$ testi sonuçları tablo 5'de sunulmuştur. Ergenlerin iyi oluş düzeyleri puan ortalamaları incelendiğinde; erkekler ve kızlar arasında önemli bir farklılık görülmemektedir. Puan ortalamaları arasında yapılan $t$ testi sonuçlarına göre de istatistiki olarak anlamlı bir fark bulunamamıştır, $t(209)=-0.14$, $\mathrm{p}=0.88$. Bu sonuçlara göre Ergenlerin iyi oluş düzeylerinde erkek ve kızların birbirlerine benzer oldukları ifade edilebilir.

Tablo 5. Ergenlerin iyi oluş düzeylerinin cinsiyete göre karşılaştırılmasına ilişkin bağımsiz örneklem t testi sonuçlan

\begin{tabular}{lllllllll}
\hline Group & $\mathbf{N}$ & Mean & SD & SE & $\mathbf{t}$ & df & p & Cohen's d \\
\hline Erkek & 74 & 67.9 & 14.4 & 1.6 & -0.14 & 209 & 0.88 & -0.021 \\
Kız & 137 & 68.2 & 13.9 & 1.1 & & & & \\
\hline
\end{tabular}

Araştırmada ergenlerin iyi oluş düzeylerinde okul türleri arasında anlamlı farkın olup olmadığı incelenmek istenmiş ve bu analize ilişkin bağımsız 
örneklem $t$ testi sonuçları Tablo 6'da sunulmuştur. Ergenlerin iyi oluş düzeyleri puan ortalamaları okul türüne göre incelendiğinde; mesleki ve teknik lisede okuyanların puanlarının anadolu lisesinde okuyanlara oranla daha düşük olduğu görülmektedir. Ancak, bu puanlar ortalamaları arasında yapılan $\mathrm{t}$ testi sonuçlarına göre istatistiki olarak anlamlı bir fark bulunamamıştır, $t(209)$ $=1.44, p=0.14$. Bu sonuçlara göre ergenlerin iyi oluş düzeylerinde okul türüne göre birbirlerine benzer oldukları ifade edilebilir.

Tablo 6.Ergenlerin iyi oluş düzeylerinin okul türleri göre karşılaştırılmasına ilişkin bağımsız örneklem t testi sonuçları

\begin{tabular}{llllllll}
\hline Group & N & Mean & SD & SE & t & df & p \\
\hline Anadolu Lisesi & 171 & 68.8 & 14.31 & 1.09 & 1.44 & 209 & 0.14 \\
Mesleki ve Teknik Lise & 40 & 65.2 & 12.9 & 2.05 & & & \\
\hline
\end{tabular}

Ergenlerin iyi oluş düzeylerinde yaşlarına göre anlamlı biçimde farklılaşıp farklılaşmadığı incelenmek istenmiş ve bu analize ilişkin ortalamalar ve standart sapmaları ile tek yönlü varyans analizi (ANOVA) sonuçları tablo 7'de sunulmuştur. Ergenlerin iyi oluş düzeylerinin yaşa göre değişimine ilişkin incelendiğinde 14 yaşındaki ergenlerde iyi oluş puanlarının diğer yaş gruplarına göre görece yüksek olduğu 16 yaşında olanlarda ise en düşük olduğu görülmektedir. Bu ortalamaların etkisini incelemek için ANOVA sonuçlarını incelediğimizde ise öğrencilerin yaşlarına göre iyi oluş puanlarında istatistiki olarak anlamlı bir şekilde farklılaşmadığı saptanmıştır, $F(4,205)=0.95, p=.43$, $\eta^{2}=.018$.

Tablo 7. İyi oluş puanlarn için yaşa göre karşılaştırmalara ilişkin tek yönlü varyans analizi (ANOVA) tablosu (levene $=.18$ )

\begin{tabular}{lllllllllll}
\hline Yaş & Mean & SD & N & Source & $\begin{array}{l}\text { Sum of } \\
\text { Squares }\end{array}$ & df & $\begin{array}{l}\text { Mean } \\
\text { Square }\end{array}$ & $\mathbf{F}$ & $\mathbf{p}$ & $\mathbf{\eta}^{2}$ \\
\hline 14 & 70.15 & 14.30 & 59 & Yaş & 760.38 & 4 & 190.09 & 0.95 & 0.43 & 0.018 \\
15 & 69.61 & 11.07 & 49 & & & & & & & \\
16 & 65.94 & 14.70 & 56 & & & & & & & \\
17 & 66.23 & 15.70 & 39 & & & & & & & \\
18 & 68.85 & 18.25 & 7 & & & & & & & \\
\hline
\end{tabular}

Ergenlerin iyi oluş düzeylerinde yetişmiş olduğu ebeveyn eğitim tutumune göre anlamlı biçimde farklılaşıp farklılaşmadığı incelenmek istenmiş ve bu analize göre yetişmiş olduğu ebeveyn eğitim tutumune ilişkin ortala- 
malar ve standart sapmaları ile tek yönlü varyans analizi (ANOVA) sonuçları tablo 8' de sunulmuştur. Ergenlerin iyi oluş düzeylerinin yetişmiş olduğu ebeveyn eğitim tutumune göre değişimine ilişkin incelendiğinde ihmalkâr olan ebeveynlerin çocuklarının iyi oluş puanlarının demokratik, otoriter ve aşırı koruyuculardan düşük olduğu görülmektedir. Diğer gruplar arasında ise göze çarpan bir fark görülmemektedir. Bu ortalamaların etkisini incelemek için ANOVA sonuçlarını incelediğimizde iyi oluş puanlarında istatistiki olarak da anlamlı bir şekilde farklılaştı̆̆ı ve etki değerinin de orta düzeyde olduğu saptanmıştır, $F(3,205)=50.6, p=.002, \eta^{2}=.07$. Bu farkın kaynağını tespit etmek için yapılan Tukey testi sonuçlarına göre; demokratik ailelerde yetişen bireylerin ihmalkar ailede yetişen bireyeler göre iyi oluşları daha yüksektir $(p=.002)$. Benzer şekilde otoriter ailelerde yetişen ergenlerin iyi oluşları ihmalkâr ailede yetişenlerden daha yüksektir $(\mathrm{p}=.001)$.

Tablo 8. İyi oluş puanlarn için içinde bulunduklarn yetişmiş olduğu ebeveyn eğitim tutumune göre karşılaştırmalara ilişkin tek yönlü varyans analizi (ANOVA) tablosu (levene= .18)

\begin{tabular}{lcccccccccc}
\hline $\begin{array}{l}\text { Ebeveyn } \\
\begin{array}{l}\text { Eğitim } \\
\text { tumu }\end{array}\end{array}$ Tu- & Mean & SD & N & Source & $\begin{array}{l}\text { Sum of } \\
\text { Squares }\end{array}$ & df & $\begin{array}{l}\text { Mean } \\
\text { Square }\end{array}$ & $\mathbf{F}$ & $\mathbf{p}$ & $\boldsymbol{\eta}^{2}$ \\
\hline Demokratik & 69.1 & 11.4 & 92 & $\begin{array}{l}\text { Gruplar } \\
\text { arası }\end{array}$ & 2.859 .6 & 3 & 953.2 & 5.06 & 0.00 & 0.0 \\
Otoriter & 69.7 & 15.1 & 82 & & & & & & & \\
İhmalkâr & 52.8 & 17.8 & 10 & & & & & & \\
Aşırı Koruyucu & 65.1 & 14.6 & 25 & & & & & & \\
\hline
\end{tabular}

Ergenlerin iyi oluş düzeylerinde sosyoekonomik duruma göre anlamlı biçimde farklılaşıp farklılaşmadığı incelenmek istenmiş ve bu analize sosyoekonomik duruma ilişkin ortalamalar ve standart sapmaları ile tek yönlü varyans analizi (ANOVA) sonuçları tablo 9'da sunulmuştur. Ergenlerin iyi oluş düzeylerinin sosyoekonomik duruma göre değişimine ilişkin incelendiğinde düşük sosyoekonomik duruma sahip ergenlerin iyi oluş puanlarının orta ve yüksek olan gruptan düşük olduğu yine orta düzeyde bulunan ergenlerinde yüksek olan gruptan daha yüksek olduğu görülmektedir. ANOVA sonuçlarını incelediğimizde ise öğrencilerin sosyoekonomik duruma göre iyi oluş puanlarında istatistiki olarak anlamlı bir şekilde farklılaşmadığı saptanmıştır, $F(2,208)=2.108, p=.12, \eta^{2}=.02$. 
Tablo 9. İyi oluş puanlarn için sosyoekonomik durum göre karşılaştırmalara ilişkin tek yönlï varyans analizi (ANOVA) tablosu (levene $=.50)$

\begin{tabular}{|c|c|c|c|c|c|c|c|c|c|c|}
\hline SED & Mean & SD & $\mathbf{N}$ & Source & $\begin{array}{l}\text { Sum of } \\
\text { Squares }\end{array}$ & df & $\begin{array}{l}\text { Mean } \\
\text { Square }\end{array}$ & F & p & $\eta^{2}$ \\
\hline Düşük & 63.3 & 16. & 29 & $\begin{array}{l}\text { Gruplar } \\
\text { arasi }\end{array}$ & 831.2 & 2 & 415.6 & 2.108 & 0.12 & 0.02 \\
\hline Orta & 69.1 & 13.6 & 172 & & & & & & & \\
\hline Yüksek & 66.6 & 15.1 & 10 & & & & & & & \\
\hline
\end{tabular}

İyi oluş düzeyleri için öğrencinin günlük internet kullanımına göre değişip değişmediği analiz edilmiştir. Günlük internet kullanımına ilişkin ortalamalar ve standart sapmalar ile varyans analizi (ANOVA) sonuçları tablo 10 'da verilmiştir. Tabloda görüleceği üzere özellikle 5 saat ve üzeri internet kullanan öğrencilerin ortalamalarınn diğerlerinden daha düşük olduğu göze çarpmaktadır. Hiç kullanmayanların ve 1 saat kullananların ise en yüksek iyi oluş puanlarına sahip oldukları görülmektedir. ANOVA sonuçlarına göre günlük internet kullanımının anlamlı olduğu tespit edilmiştir $(F(5,205)=3.38, \mathrm{p}$ $=0.006, \eta^{2}=0.8$ ). Bu etkinin orta düzeyde etki büyüklügüne sahip olduğu görülmüştür. Anlamlı çkan sonucun hangi gruplar arasında olduğunu belirlemek için Tukey testi yapılmıştır. Post hoc analizi sonuçlarına 1 saat internet kullanan öğrencilerin iyi oluşları 5 ve üzeri saat kullananlara göre anlamlı bir şekilde daha yüksektir ( $\mathrm{p}=.008)$. Yine benzer şekilde 2 saat internet kullanan bireylerin 5 saat ve üstü kullanan bireylere göre iyi oluşları daha yüksek$\operatorname{tir}(\mathrm{p}=.03)$ Sonuç olarak daha az saat internet kullanan ergenlerin iyi oluşları daha yüksek saatler internet kullananlara göre daha yüksektir.

Tablo 10. İyi oluş puanları için günlük internet kullanımına göre gruplar arası karşılaştırmalara ilişkin ANOVA tablosu (levene= .21)

\begin{tabular}{lccccccccccc}
\hline $\begin{array}{l}\text { Günlük } \\
\text { internet } \\
\text { kullanımı }\end{array}$ & Mean & SD & N & Source & $\begin{array}{l}\text { Sum of } \\
\text { Squares }\end{array}$ & df & $\begin{array}{l}\text { Mean } \\
\text { Square }\end{array}$ & F & p & $\boldsymbol{\eta}^{2}$ \\
\hline Hiç & 74.1 & 14.4 & 7 & $\begin{array}{l}\text { Gruplar } \\
\text { aras1 }\end{array}$ & 3.187 & 5 & 637.4 & 3.38 & 0.006 & 0.08 \\
1 Saat & 72.7 & 13.4 & 38 & & & & & & & \\
2 Saat & 70.4 & 13.8 & 57 & & & & & & & \\
3 Saat & 66.9 & 11.4 & 59 & & & & & & & \\
4 Saat & 64.8 & 15.3 & 24 & & & & & & & \\
5+ Saat & 60.6 & 16.6 & 26 & & & & & & & \\
\hline
\end{tabular}


Ebeveyni Boşanmış Ve Ebeveyni Evli Ergenlerin İnternet bağımlılı̆̆ının Ebeveyni boşanmış ve ebeveyni evli olması, Cinsiyet, Öğrenim Gördüğ̈̈ Okul Türü, Yaş, Yetiştiği Ĕ̆itim Stili, Sosyoekonomik Duruma ve Günlük İnternet Kullanımına Göre İncelenmesine İlişkin Bulgular

Araştırmanın diğer bağımlı değişkeni olan internet bağımlılığı için de benzer analizler gerçekleştirilmiştir. Araştırmada öğrencilerin internet bağımlılı̆̆1nın ebeveyni boşanmış ve ebeveyni evli ergenlere göre incelenmesi amaçlanmıştır. $\mathrm{Bu}$ amaç doğrultusunda yapılan $\mathrm{t}$ testi sonuçları tablo 11 'de sunulmuştur. Tabloda görüleceği üzere internet bağımlılığı puanları incelendiğinde ebeveyni boşanmış ergenlerin ebeveyni evli ergenlere göre biraz daha yüksek ortalamaya sahip olduğu ama bu farkın istatistiki olarak anlamlı olmadığ görülmektedir $t(209)=-0.75, p=0.45$. Sonuç olarak internet bağımlılığ 1 düzeyi ebeveyninin boşanmış veya ebeveyni evli olmasına göre bir değişiklik göstermemektedir.

Tablo 11. Internet bağımlılı̆̆ı düzeyleri ebeveyni boşanmış ve ebeveyni evli ergenlere göre karşılaştırılmasına ilişkin t test tablosu (Levene: 0.6)

\begin{tabular}{lllllllll}
\hline Group & N & Mean & SD & SE & t & df & p & Cohen's d \\
\hline Evli & 109 & 28.5 & 9.1 & 0.8 & -0.75 & 209 & 0.45 & -0.10 \\
Boşanmış & 102 & 29.5 & 10.1 & 0.9 & & & & \\
\hline
\end{tabular}

Araştırmada ergenlerin internet bağımlılığı düzeylerinde erkek ve kızlar arasında anlamlı farkın olup olmadığı incelenmek istenmiş ve bu analize ilişkin bağımsız örneklem $t$ testi sonuçlar tablo 12 'de sunulmuştur. Ergenlerin internet bağımlılığı düzeyleri puan ortalamaları incelendiğinde; erkekler ve kızlar arasında önemli bir farklılık görülmemektedir. Puan ortalamaları arasında yapılan $t$ testi sonuçlarına göre de istatistiki olarak anlamlı bir fark bulunamamıştır, $t(209)=0.33, p=0.73$. Bu sonuçlara göre ergenlerin internet bağımlılığı düzeylerinde erkek ve kızların birbirlerine benzer oldukları ifade edilebilir.

Tablo 12. Ergenlerin internet bağımlılı̆̆ı düzeylerinin cinsiyete göre karşılaştırılmasına ilişkin bağımsız örneklem t testi sonuçlan (levene:32)

\begin{tabular}{llllllll}
\hline Group & $\mathbf{N}$ & Mean & SD & SE & t & df & p \\
\hline Erkek & 74 & 29.2 & 10.2 & 1.1 & 0.33 & 209 & 0.73 \\
Kiz & 137 & 28.8 & 9.2 & 0.7 & & & \\
\hline
\end{tabular}


Araştırmada ergenlerin internet bağımlılığı düzeylerinde okul türleri arasında anlamlı farkın olup olmadığ 1 incelenmek istenmiş ve bu analize ilişkin bağımsız örneklem t testi sonuçları tablo 13'de sunulmuştur. Ergenlerin internet bağımlılığı düzeyleri puan ortalamaları okul türüne göre incelendiğinde; mesleki ve teknik lisede okuyanların puanlarının anadolu lisesinde okuyanlarla benzer olduğu görülmektedir. Bu puanlar ortalamaları arasında yapılan $\mathrm{t}$ testi sonuçlarına göre istatistiki olarak anlamlı bir fark bulunamamıştır, $t(209)=-0.02, p=0.98$. Bu sonuçlara göre ergenlerin internet bağımlılığı düzeylerinde okul türüne göre birbirlerine benzer oldukları ifade edilebilir.

Tablo 13. Ergenlerin internet bağımlılı̆̆ı düzeylerinin okul türleri göre karşılaştırılmasına ilişkin bağımsız örneklem t testi sonuçlan (levene:71)

\begin{tabular}{llllllll}
\hline Group & N & Mean & SD & SE & t & df & p \\
\hline Anadolu Lisesi & 171 & 28.9 & 9.5 & 0.7 & -0.02 & 209 & 0.98 \\
Mesleki ve Teknik Lise & 40 & 29 & 10 & 1.5 & & & \\
\hline
\end{tabular}

Ergenlerin internet bağımlılığı düzeylerinde yaşlarına göre anlamlı biçimde farklılaşıp farklılaşmadığ incelenmek istenmiş ve bu analize ilişkin ortalamalar ve standart sapmaları ile tek yönlü varyans analizi (ANOVA) sonuçları tablo 14'te sunulmuştur. Ergenlerin internet bağımlılı̆̆ı düzeylerinin yaşa göre değişimine ilişkin incelendiğinde 16 ve 17 yaşındaki ergenlerde internet bağımlılığı puanlarının diğer yaş gruplarına göre görece yüksek olduğu 18 yaşında olanlarda ise en düşük olduğu görülmektedir. Bu ortalamaların etkisini incelemek için ANOVA sonuçlarını incelediğimizde ise öğrencilerin yaşlarına göre internet bağımlılı̆̆ puanlarında istatistiki olarak anlamlı bir şekilde farklılaşmadığı saptanmıştır, $F(4,205)=1.25, p=.28, \eta^{2}=.024$.

Tablo 14. Internet bağımlılı̆̆ı puanları için yaşa göre karşılaştırmalara ilişkin tek yönlü varyans analizi (ANOVA) tablosu (levene $=.05)$

\begin{tabular}{lllllllllll}
\hline Yaş & Mean & SD & $\mathbf{N}$ & Source & $\begin{array}{l}\text { Sum of } \\
\text { Squares }\end{array}$ & df & $\begin{array}{l}\text { Mean } \\
\text { Square }\end{array}$ & $\mathbf{F}$ & $\mathbf{p}$ & $\boldsymbol{\eta}^{2}$ \\
\hline 14 & 27.08 & 7.74 & 59 & $\begin{array}{l}\text { Gruplar } \\
\text { arasi }\end{array}$ & 464.07 & 4 & 116.01 & 1.27 & 0.28 & 0.024 \\
15 & 28.81 & 9.45 & 49 & & & & & & & \\
16 & 30.50 & 11.18 & 56 & & & & & & \\
17 & 30.15 & 9.64 & 39 & & & & & & \\
18 & 25.85 & 8.39 & 7 & & & & & & \\
\hline
\end{tabular}


Ergenlerin internet bağımlılığı düzeylerinde yetişmiş olduğu ebeveyn eğitim tutumune göre anlamlı biçimde farklılaşıp farklılaşmadığı incelenmek istenmiş ve bu analize yetişmiş olduğu ebeveyn eğitim tutumune ilişkin ortalamalar ve standart sapmaları ile tek yönlü varyans analizi (ANOVA) sonuçları tablo 15'de sunulmuştur. Ergenlerin internet bağımlılığı düzeylerinin yetişmiş olduğu ebeveyn eğitim tutumune göre değişimi incelendiğinde ihmalkâr olan ebeveynlerin çocuklarının internet bağımlllı̆ı puanlarının demokratik, otoriter ve aşırı koruyuculardan düşük olduğu görülmektedir. Diğer gruplar arasında ise göze çarpan bir fark görülmemektedir. Bu ortalamaların etkisini incelemek için ANOVA sonuçlarını incelediğimizde internet bağımlılı̆̆ puanlarında istatistiki olarak da anlamlı bir şekilde farklılaşmadığı görülmektedir $F(3,205)=1.42, p=.23, \eta^{2}=.02$.

Tablo 15. Internet bağımlılı̆̆ı puanlar için içinde bulunduklan yetişmiş olduğu ebeveyn eğitim tutumune göre karşılaştırmalara ilişkin tek yönlü varyans analizi (ANOVA) tablosu (levene= .85)

\begin{tabular}{lcccccccccc}
\hline $\begin{array}{l}\text { Ebeveyn } \\
\text { eğitim tutumu }\end{array}$ & Mean & SD & $\mathbf{N}$ & Source & $\begin{array}{l}\text { Sum of } \\
\text { Squares }\end{array}$ & df & $\begin{array}{l}\text { Mean } \\
\text { Square }\end{array}$ & F & p & $\eta^{2}$ \\
\hline Demokratik & 28.3 & 8.7 & 92 & $\begin{array}{l}\text { Grup- } \\
\text { lar } \\
\text { arası }\end{array}$ & 393.81 & 3 & 131.2 & 1.428 & 0.23 & 0.02 \\
Otoriter & 28.4 & 10.2 & 82 & & & & & & & \\
İhmalkâr & 33.5 & 10.4 & 10 & & & & & & & \\
Aşırı Koruyucu & 31.3 & 10.1 & 25 & & & & & & & \\
\hline
\end{tabular}

Ergenlerin internet bağımlılığı düzeylerinde sosyoekonomik duruma göre anlamlı biçimde farklılaşıp farklılaşmadığı incelenmek istenmiş ve bu analize göre sosyoekonomik duruma ilişkin ortalamalar ve standart sapmaları ile tek yönlü varyans analizi (ANOVA) sonuçları tablo 16'da sunulmuştur. Ergenlerin internet bağımlılı̆̆ düzeylerinin sosyoekonomik duruma göre değişimi incelendiğinde düşük sosyoekonomik duruma sahip ergenlerin internet bağımlılığı puanlarının orta ve yüksek olan gruptan yüksek olduğu yine görülmektedir. ANOVA sonuçlarını incelediğimizde ise öğrencilerin sosyoekonomik duruma göre internet bağımlılığı puanlarında istatistiki olarak anlamlı bir şekilde farklılaşmadığı saptanmıştır, $F(2,208)=1.45, p=.23$, $\eta^{2}=.014$. 
Tablo 16. Internet bağımlılı̆̆ı puanlarn için sosyoekonomik durum göre karşılaştırmalara ilişkin tek yönlï varyans analizi (ANOVA) tablosu (levene= .35)

\begin{tabular}{lllllllllll}
\hline SED & Mean & SD & N & Source & $\begin{array}{l}\text { Sum of } \\
\text { Squares }\end{array}$ & df & $\begin{array}{l}\text { Mean } \\
\text { Square }\end{array}$ & $\mathbf{F}$ & p & $\boldsymbol{\eta}^{2}$ \\
\hline Düşük & 31.6 & 11.2 & 29 & $\begin{array}{l}\text { Gruplar } \\
\text { aras1 }\end{array}$ & 265.8 & 2 & 132.9 & 1.455 & 0.23 & 0.014 \\
$\begin{array}{l}\text { Orta } \\
\text { Yüksek }\end{array}$ & $\begin{array}{l}28.4 \\
30\end{array}$ & 9.2 & $\begin{array}{l}172 \\
10\end{array}$ & & & & & & & \\
\hline
\end{tabular}

İnternet bağımlılığı düzeyleri için öğrencinin günlük internet kullanımına göre değişip değişmediği analiz edilmiştir. Günlük internet kullanımına ilişkin ortalamalar, standart sapmalar ve varyans analizi (ANOVA) sonuçları tablo 17'de verilmiştir. Tabloda görüleceği üzere özellikle 5 saat ve üzeri internet kullanan öğrencilerin ortalamalarının diğerlerinden daha yüksek olduğu göze çarpmaktadır. Hiç kullanmayanların ve 1 saat kullananların da en düşük internet bağımlılığı puanlarına sahip oldukları görülmektedir. ANOVA sonuçlarına göre günlük internet kullanımının anlamlı olduğu tespit edilmiştir $\left(F(5,205)=14.27, p=0.001, \eta^{2}=0.25\right)$. Bu etkinin büyük düzeyde etki büyüklüğüne sahip olduğu görülmüştür. Anlamlı çıan sonucun hangi gruplar arasında olduğunu belirlemek için Tukey testi yapılmıştır. Post hoc analizi sonuçlarına göre 5 saat internet kullanan öğrencilerin internet bağımlılıkları hiç kullanmayanlara göre anlamlı bir şekilde daha yüksektir ( $\mathrm{p}=.001)$. Yine benzer şekilde 3 saat internet kullanan( $(\mathrm{p}=.001)$, 4 saat kullanan $(\mathrm{p}=.001)$ ve 5 saat ve üstü kullanan ( $\mathrm{p}=.001$ ) bireylerin internet bağımlılıkları 1 saat kullananlara göre daha yüksektir. Diğer yandan 5 saat ve üstü kullananlarda ise 2 saat kullananlardan anlamlı bir şekilde daha yüksektir $(\mathrm{p}=.001)$. Benzer şekilde 5 saat ve üstü kullananlarda 3 saat kullananlardan anlamlı bir şekilde daha yüksektir $(\mathrm{p}=.001)$. Sonuç olarak internet kullanma süresi 5 saat ve üzerine yaklaştıkça internet bağımlılığı artmakta, yüksek saatlerde internet kullanımı internet bağımlılığını artırmaktadır. 
Tablo 17. Internet bağımlılı̆̆ı puanlarn için günlük internet kullanımına göre gruplar arası karşılaştırmalara ilişkin ANOVA tablosu (levene= .11)

\begin{tabular}{lllllllllll}
\hline $\begin{array}{l}\text { Günlük internet } \\
\text { kullanımı }\end{array}$ & Mean & SD & $\mathbf{N}$ & Source & $\begin{array}{l}\text { Sum of } \\
\text { Squares }\end{array}$ & df & $\begin{array}{l}\text { Mean } \\
\text { Square }\end{array}$ & F & p & $\eta^{2}$ \\
\hline Hiç & 22.5 & 10.1 & 7 & $\begin{array}{l}\text { Gruplar } \\
\text { arası }\end{array}$ & 4.978 & 5 & 995.6 & 14.27 & .001 & 0.25 \\
1 Saat & 22.4 & 6.3 & 38 & & & & & & & \\
2 Saat & 26.9 & 8.1 & 57 & & & & & & & \\
3 Saat & 30.3 & 8.5 & 59 & & & & & & & \\
4 Saat & 32.1 & 7.8 & 24 & & & & & & & \\
5+Saat & 38.7 & 10.8 & 26 & & & & & & & \\
\hline
\end{tabular}

Ebeveyni boşanmış ergenlerin İyi Oluş düzeylerinin Cinsiyet, Öğrenim Gördüğ̈̈ Okul Türü, Yaş, Yetiştiği Eğitim Stili, Sosyoekonomik Duruma ve Günlïk İnternet Kullanımına Göre İncelenmesine İlişkin Bulgular

Araştırmada ebeveyni boşanmış ergenlerin iyi oluş düzeylerinde erkek ve kızlar arasında anlamlı farkın olup olmadığı incelenmek istenmiş ve bu analize ilişkin bağımsız örneklem $t$ testi analizi gerçekleştirilmiştir. Ebeveyni boşanmış ergenlerin iyi oluş düzeyleri puan ortalamaları incelendiğinde; erkekler $(M=66.97, S D=12.28)$ ve kızlar $(M=66.03, S D=15.65)$ arasında önemli bir farklılık görülmemektedir. Puan ortalamaları arasında yapılan $t$ testi sonuçlarına göre de istatistiki olarak anlamlı bir fark bulunamamıştır, $\mathrm{t}(100)=$ $0.33, p=0.74$. Bu sonuçlara göre ebeveyni boşanmış ergenlerin iyi oluş düzeylerinde erkek ve kızların birbirlerine benzer oldukları ifade edilebilir.

Araştırmada ebeveyni boşanmış ergenlerin iyi oluş düzeylerinde okul türleri arasında anlamlı farkın olup olmadığı incelenmek istenmiş ve bu analize ilişkin bağımsız örneklem $t$ testi gerçekleştirilmiştir. Ebeveyni boşanmış ergenlerin iyi oluş düzeyleri puan ortalamaları okul türüne göre incelendiğinde; mesleki ve teknik lisede okuyanların puanlarının $(\mathrm{M}=64.12, \mathrm{SD}=$ 15.13) anadolu lisesinde okuyanlara $(M=66.90, S D=14)$ oranla görece düşük olduğu görülmektedir. Ancak, bu puanlar ortalamaları arasında yapılan $\mathrm{t}$ testi sonuçlarına göre istatistiki olarak anlamlı bir fark bulunamamıştır, $t_{(100)}$ $=0.72, p=0.47$. Bu sonuçlara göre ebeveyni boşanmış ergenlerin iyi oluş düzeylerinde okul türüne göre birbirlerine benzer oldukları ifade edilebilir.

Ebeveyni boşanmış ergenlerin iyi oluş düzeylerinde yaşlarına göre anlamlı biçimde farklılaşıp farklılaşmadığı incelenmek istenmiş, bu analize ilişkin ortalamalar ile standart sapmaları belirlenmiş ve tek yönlü varyans ana- 
lizi (ANOVA) gerçekleştirilmiştir. Ebeveyni boşanmış ergenlerin iyi oluş düzeylerinin yaşa göre değişimi incelendiğinde $15(\mathrm{M}=67.96, \mathrm{SD}=9.6)$ ve 17 $(\mathrm{M}=67.04, \mathrm{SD}=15.99)$ yaşındaki ergenlerde iyi oluş puanlarının diğer yaş gruplarına göre görece yüksek olduğu 18 yaşında olanlarda ise $(M=58.50$, $\mathrm{SD}=15.37$ ) en düşük olduğu görülmektedir. Bu ortalamaların etkisini incelemek için ANOVA sonuçlarını incelediğimizde ise öğrencilerin yaşlarına göre iyi oluş puanlarında istatistiki olarak anlamlı bir şekilde farklılaşmadığı saptanmıştır, $F(5,96)=0.33, p=.89, \eta^{2}=.017$. (levene $=.38$ )

Ebeveyni boşanmış ergenlerin iyi oluş düzeylerinde yetişmiş olduğu ebeveyn eğitim tutumune göre anlamlı biçimde farklılaşıp farklılaşmadığı incelenmek istenmiş, bu analize göre yetişmiş olduğu ebeveyn eğitim tutumune ilişkin ortalamalar ile standart sapmaları belirlenmiş, tek yönlü varyans analizi (ANOVA) gerçekleştirilmiş ve sonuçlar tablo 18'de sunulmuştur. Ebeveyni boşanmış ergenlerin iyi oluş düzeylerinin yetişmiş olduğu ebeveyn eğitim tutumune göre değişimine ilişkin incelendiğinde ihmalkâr olan ebeveynlerin çocuklarının iyi oluş puanlarının demokratik, otoriter ve aşırı koruyuculardan düşük olduğu görülmektedir. Diğer gruplar arasında ise göze çarpan bir fark görülmemektedir. Bu ortalamaların etkisini incelemek için ANOVA sonuçlarını incelediğimizde iyi oluş puanlarında istatistiki olarak da anlamlı bir şekilde farklılaştığı ve etki değerinin de orta düzeyde olduğu saptanmıştır, $F(3,98)=4.59, p=.005, \eta^{2}=.12$. Bu farkın kaynağını tespit etmek için yapılan Tukey testi sonuçlarına göre; demokratik ailelerde yetişen bireylerin ihmalkâr ailede yetişen bireylere göre iyi oluşları daha yüksektir ( $\mathrm{p}=.01)$. Benzer şekilde otoriter ailelerde yetişen ebeveyni boşanmış ergenlerin iyi oluşları ihmalkâr ailede yetişenlerden $(\mathrm{p}=.002)$ ve aşırı koruyucu ailede yetişenlerinde ihmalkâr ailede yetişenlerden $(\mathrm{p}=.04)$ daha yüksektir. Sonuç olarak ihmalkâr ailelerde yetişen ergenlerin iyi oluş düzeyleri diğer eğitim stillerinde yetişenlere göre daha düşüktür.

Tablo 18. Ebeveyni boşanmış ergenlerin iyi oluş puanlarn için içinde bulundukları yetişmiş olduğu ebeveyn eğitim tutumune göre karşılaştırmalara ilişkin tek yönlü varyans analizi (ANOVA) tablosu (levene= .15)

\begin{tabular}{lccclllllll}
\hline $\begin{array}{l}\text { Ebeveyn } \\
\text { Eğitim Stili }\end{array}$ & Mean & SD & N & Source & $\begin{array}{l}\text { Sum of } \\
\text { Squares }\end{array}$ & df & $\begin{array}{l}\text { Mean } \\
\text { Square }\end{array}$ & F & p & $\boldsymbol{\eta}^{2}$ \\
\hline Demokratik & 66.47 & 10.65 & 36 & Gruplar arası & 2.491 & 3 & 830.6 & 4.59 & 0.005 & 0.12 \\
Otoriter & 69.71 & 14.73 & 42 & & & & & & & \\
İhmalkar & 49.42 & 17.93 & 7 & & & & & & & \\
Aşırı Koruyucu & 65.47 & 13.48 & 17 & & & & & & & \\
\hline
\end{tabular}


Ebeveyni boşanmış ergenlerin iyi oluş düzeylerinde sosyoekonomik duruma göre anlamlı biçimde farklılaşıp farklılaşmadığı incelenmek istenmiş, sosyoekonomik duruma ilişkin ortalamalar ile standart sapmaları belirlenmiş ve tek yönlü varyans analizi (ANOVA) gerçekleştirilmiştir. Ebeveyni boşanmış ergenlerin iyi oluş düzeylerinin sosyoekonomik duruma göre değişimine ilişkin incelendiğinde düşük sosyoekonomik duruma sahip ergenlerin iyi oluş puanlarının $(\mathrm{M}=61.40, \mathrm{SD}=16.72) \quad$ orta $(\mathrm{M}=67.58, \mathrm{SD}=13.21) \quad$ ve yüksek (M=68.66, SD = 14.44) olan gruptan düşük olduğu tespit edilmiştir. ANOVA sonuçlarını incelediğimizde ise öğrencilerin sosyoekonomik duruma göre iyi oluş puanlarında istatistiki olarak anlamlı bir şekilde farklılaşmadığ 1 saptanmıştır, $F(2,99)=1.64, p=.19, \eta^{2}=.03$. (levene $=.31$ )

İyi oluş düzeyleri için öğrencinin günlük internet kullanımına göre değişip değişmediği analiz edilmiştir. Günlük internet kullanımına ilişkin ortalamalar ile standart sapmalar belirlenmiş ve varyans analizi (ANOVA) gerçekleştirilmiştir. Sonuçlara göre özellikle 5 saat ve üzeri internet kullanan öğrencilerin ortalamalarının $(\mathrm{M}=57.53, \mathrm{SD}=17.11) \quad$ diğerlerinden daha düşük olduğu göze çarpmaktadır. Hiç kullanmayanların $(\mathrm{M}=79.25, \mathrm{SD}=3.86)$ ve 1 saat kullananların $(\mathrm{M}=70.52, \mathrm{SD}=13.88)$ da en yüksek iyi oluş puanlarına sahip oldukları görülmektedir. ANOVA sonuçlarına göre günlük internet kullanımının kullanılan saate göre anlamlı olmadığı tespit edilmiştir $\left(\mathrm{F}_{(5,96)}=\right.$ 2.11, $\mathrm{p}=0.07, \eta^{2}=0.9$ (levene $\left.=.17\right)$

\section{Ebeveyni boşanmış ergenlerin İnternet bă̆ımlılı̆̆ı düzeylerinin Cinsiyet, Ö̆̆- renim Gördüğü Okul Türü, Yaş, Yetiştiği Ĕ̆itim Stili, Sosyoekonomik Du- ruma ve Günlük Internet Kullanımına Göre Incelenmesine İlişkin Bulgular}

Araştırmada ebeveyni boşanmış ergenlerin internet bağımlılı̆̆ı düzeylerinde erkek ve kızlar arasında anlamlı farkın olup olmadığı incelenmek istenmiş ve bu analize ilişkin bağımsız örneklem t testi analizi gerçekleştirilmiştir. Ebeveyni boşanmış ergenlerin internet bağımlılığı düzeyleri puan ortalamaları incelendiğinde, erkekler $(M=29.27, S D=9.68)$ ve k1zlar $(M=29.70, S D=10.39)$ arasında önemli bir farklılık görülmemektedir. Puan ortalamaları arasında yapılan $t$ testi sonuçlarına göre de istatistiki olarak anlamlı bir fark bulunamamiştır, $\mathrm{t}(100)=-0.21, \mathrm{p}=0.82$ (levene= .52). Bu sonuçlara göre ebeveyni boşanmış ergenlerin internet bağımlılığı düzeylerinde erkek ve kızların birbirlerine benzer oldukları ifade edilebilir. 
Araştırmada ebeveyni boşanmış ergenlerin internet bağımlılığı düzeylerinde okul türleri arasında anlamlı farkın olup olmadığ incelenmek istenmiş ve bu analize ilişkin bağımsız örneklem $t$ testi gerçekleştirilmiştir. Ebeveyni boşanmış ergenlerin internet bağımlılığı düzeyleri puan ortalamaları okul türüne göre incelendiğinde, mesleki ve teknik lisede okuyanların puanlarının $(\mathrm{M}=28.18, \mathrm{SD}=9.62)$ anadolu lisesinde okuyanlara $(\mathrm{M}=29.76, \mathrm{SD}=10.13)$ oranla görece düşük olduğu görülmektedir. Ancak, bu puanlar ortalamaları arasında yapılan $\mathrm{t}$ testi sonuçlarına göre istatistiki olarak anlamlı bir fark bulunamamıştır, $t_{(100)}=0.57, p=0.56$ (levene $=.61$ ). Bu sonuçlara göre ebeveyni boşanmış ergenlerin internet bağımlılığı düzeylerinde okul türüne göre birbirlerine benzer oldukları ifade edilebilir.

Ebeveyni boşanmış ergenlerin internet bağımlılığı düzeylerinde yaşlarına göre anlamlı biçimde farklılaşıp farklılaşmadığı incelenmek istenmiş, bu analize ilişkin ortalamalar ile standart sapmaları belirlenmiş ve tek yönlü varyans analizi (ANOVA) gerçekleştirilmiştir. Ebeveyni boşanmış ergenlerin internet bağımlılığı düzeylerinin yaşa göre değişimi incelendiğinde $16(\mathrm{M}=31.35$, SD $=12.01)$ ve $18(\mathrm{M}=31.50, \mathrm{SD}=4.20)$ yaşındaki ergenlerde internet bağımlılığı puanlarının diğer yaş gruplarına göre görece yüksek olduğu 15 yaşında olanlarda ise ( $\mathrm{M}=27.95, \mathrm{SD}=9.97)$ en düşük olduğu görülmektedir. Bu ortalamaların etkisini incelemek için ANOVA sonuçlarını incelediğimizde ise öğrencilerin yaşlarına göre internet bağımlılığı puanlarında istatistiki olarak anlamlı bir şekilde farklılaşmadığı saptanmıştır, $F(5,96)=0.62, p=.68, \eta^{2}=.031$ (levene $=.20$ ).

Ebeveyni boşanmış ergenlerin internet bağımlılığı düzeylerinde yetişmiş olduğu ebeveyn eğitim tutumune göre anlamlı biçimde farklılaşıp farklılaşmadığ 1 incelenmek istenmiş ve bu analize yetişmiş olduğu ebeveyn eğitim tutumune ilişkin ortalamalar ile standart sapmaları belirlenmiş ve tek yönlü varyans analizi (ANOVA) gerçekleşirmiştir. Ebeveyni boşanmış ergenlerin internet bağımlılığı düzeylerinin yetişmiş olduğu ebeveyn eğitim tutumune göre değişimine ilişkin incelendiğinde ihmalkâr olan ebeveynlerin çocuklar1nın internet bağımlılığı puanlarının $(\mathrm{M}=36, \mathrm{SD}=9.30)$ demokratik $(\mathrm{M}=$ $28.72, \mathrm{SD}=9.30)$, otoriter $(\mathrm{M}=28.59, \mathrm{SD}=10.82)$ ve aşırı koruyuculardan $(\mathrm{M}$ $=30.76, \mathrm{SD}=9.42$ ) düşük olduğu görülmektedir. Diğer gruplar arasında ise göze çarpan bir fark görülmemektedir. Bu ortalamaların etkisini incelemek 
için ANOVA sonuçlarını incelediğimizde internet bağımlılığı puanlarında istatistiki olarak da anlamlı bir şekilde farklılaşmadığı saptanmıştır, $F(3,98)=$ $1.26, p=.29, \eta^{2}=.037$ (levene $=.48$ ).

Ebeveyni boşanmış ergenlerin internet bağımlılığı düzeylerinde sosyoekonomik duruma göre anlamlı biçimde farklılaşıp farklılaşmadığı incelenmek istenmiş ve sosyoekonomik duruma ilişkin ortalamalar ile standart sapmaları belirlenmiş ve tek yönlü varyans analizi (ANOVA) gerçekleştirilmiştir. Ebeveyni boşanmış ergenlerin internet bağımlılı̆̆ı düzeylerinin sosyoekonomik duruma göre değişimine ilişkin incelendiğinde orta sosyoekonomik duruma sahip ergenlerin internet bağımlılığı puanlarının $(\mathrm{M}=25.84, \mathrm{SD}=$ 9.69) düşük ( $\mathrm{M}=31.50, \mathrm{SD}=11.24)$ ve yüksek $(\mathrm{M}=30.44, \mathrm{SD}=10.38)$ olan gruptan düşük olduğu tespit edilmiştir. ANOVA sonuçlarını incelediğimizde ise öğrencilerin sosyoekonomik duruma göre internet bağımlılığı puanlarında istatistiki olarak anlamlı bir şekilde farklılaşmadığı saptanmıştır, $F$ $(2,99)=0.58, p=.56, \eta^{2}=.012$. (levene $=.84$ )

İnternet bağımlılığı düzeyleri için öğrencinin günlük internet kullanımına göre değişip değişmediği analiz edilmiştir. Günlük internet kullanımına ilişkin ortalamalar ile standart sapmalar ve varyans analizi (ANOVA) sonuçları tablo 19'da verilmiştir. Tabloda görüleceği üzere özellikle 5 saat ve üzeri internet kullanan öğrencilerin ortalamalarının diğerlerinden daha yüksek olduğu göze çarpmaktadır. 1 saat kullananların da en düşük internet bağımlılığı puanlarına sahip oldukları görülmektedir. ANOVA sonuçlarına göre günlük internet kullanımının anlamlı olduğu tespit edilmiştir $\left(\mathrm{F}_{(4,97)}=9.98, \mathrm{p}\right.$ $\left.=0.001, \eta^{2}=0.34\right)$. Bu etkinin büyük düzeyde etki büyüklüğüne sahip olduğu görülmüştür. Anlamlı çıkan sonucun hangi gruplar arasında olduğunu belirlemek için Tukey testi yapılmıştır. Post hoc analizi sonuçlarına göre 5 saat ve üstü internet kullanan öğrencilerin internet bağımlılıkları 1 saat kullananlara $(\mathrm{p}=.001), 2$ saat kullananlara $(\mathrm{p}=.001), 3$ saat kullananlara $(\mathrm{p}=.01)$ göre anlamlı bir şekilde daha yüksektir. Yine benzer şekilde 4 saat internet kullanan bireylerin internet bağımlılıkları 1 saat kullananlara göre daha yüksektir $(\mathrm{p}=.01)$. Benzer şekilde 3 saat kullananlarda da 1 saat kullananlara göre anlamlı bir şekilde daha yüksektir $(\mathrm{p}=.01)$. Sonuç olarak internet kullanma süresi 5 saat ve üzerine yaklaştıkça internet bağımlılı̆̆ı artmakta, yüksek saatlerde internet kullanımı internet bağımlılığını artırmaktadır. 
Tablo 19. Ebeveyni boşanmış ergenlerin internet bağımlılı̆̆ puanlar için günlük internet kullanımına göre gruplar arası karşılaştırmalara ilişkin ANOVA tablosu (levene $=.27$ )

\begin{tabular}{|c|c|c|c|c|c|c|c|c|c|c|}
\hline $\begin{array}{l}\text { Günlük } \\
\text { internet } \\
\text { kullanımı }\end{array}$ & Mean & SD & $\mathbf{N}$ & Source & $\begin{array}{l}\text { Sum } \\
\text { of } \\
\text { Squares }\end{array}$ & df & $\begin{array}{l}\text { Mean } \\
\text { Square }\end{array}$ & F & p & $\eta^{2}$ \\
\hline 1 Saat & 22.70 & 7.1 & 17 & $\begin{array}{l}\text { Grup- } \\
\text { lar } \\
\text { aras1 }\end{array}$ & 3.472 & 4 & 694.5 & 9.98 & .001 & 0.34 \\
\hline 2 Saat & 28.03 & 8.8 & 30 & & & & & & & \\
\hline 3 Saat & 30.79 & 7.5 & 24 & & & & & & & \\
\hline 4 Saat & 32.78 & 8.3 & 14 & & & & & & & \\
\hline $5+$ Saat & 40.46 & 10.5 & 13 & & & & & & & \\
\hline
\end{tabular}

Ebeveyni evli ergenlerin İyi Oluş düzeylerinin Cinsiyet, Öğrenim Gördü̈̆̈̈ Okul Türü, Yaş, Yetiştiği Eğitim Stili, Sosyoekonomik Duruma ve Günlük Internet Kullanımına Göre İncelenmesine İlişkin Bulgular

Araştırmada ebeveyni evli ergenlerin iyi oluş düzeylerinde erkek ile kızlar arasında anlamlı farkın olup olmadığ 1 incelenmek istenmiş ve bu analize ilişkin bağımsız örneklem t testi analizi gerçekleştirilmiştir. Ebeveyni evli ergenlerin iyi oluş düzeyleri puan ortalamaları incelendiğinde, erkekler $(M=69.74$, $S D=17.83)$ ve kızlar $(M=69.78, S D=12.56)$ arasında önemli bir farklılık görülmemektedir. Puan ortalamaları arasında yapılan $t$ testi sonuçlarına göre de istatistiki olarak anlamlı bir fark bulunamamıştır, $\mathrm{t}(107)=-0.013, \mathrm{p}=0.99$. Bu sonuçlara göre ebeveyni evli ergenlerin iyi oluş düzeylerinde erkek ve kızların birbirlerine benzer oldukları ifade edilebilir.

Araştırmada ebeveyni evli ergenlerin iyi oluş düzeylerinde okul türleri arasında anlamlı farkın olup olmadığ incelenmek istenmiş ve bu analize ilişkin bağımsız örneklem t testi gerçekleştirilmiştir. Ebeveyni evli ergenlerin iyi oluş düzeyleri puan ortalamaları okul türüne göre incelendiğinde, mesleki ve teknik lisede okuyanların puanlarının $(\mathrm{M}=66.04, \mathrm{SD}=11.62)$ anadolu lisesinde okuyanlara $(\mathrm{M}=70.82, \mathrm{SD}=14.44)$ oranla görece düşük olduğu görülmektedir. Ancak, bu puanlar ortalamaları arasında yapılan $t$ testi sonuçlarına göre istatistiki olarak anlamlı bir fark bulunamamıştır, $t(107)=0.72, p=0.14$. Bu sonuçlara göre ebeveyni evli ergenlerin iyi oluş düzeylerinde okul türüne göre birbirlerine benzer oldukları ifade edilebilir. 
Ebeveyni evli ergenlerin iyi oluş düzeylerinde yaşlarına göre anlamlı biçimde farklılaşıp farklılaşmadığı incelenmek istenmiş ve bu analize ilişkin ortalamalar ile standart sapmaları belirlenmiş ve tek yönlü varyans analizi (ANOVA) gerçekleştirilmiştir. Ebeveyni evli ergenlerin iyi oluş düzeylerinin yaşa göre değişimi incelendiğinde $14(\mathrm{M}=72, \mathrm{SD}=13.56)$ ve $15(\mathrm{M}=71.07$, $\mathrm{SD}=12.19$ ) yaşındaki ergenlerde iyi oluş puanlarının diğer yaş gruplarına göre görece yüksek olduğu 17 yaşında olanlarda ise $(M=64.78, S D=15.65)$ en düşük olduğu görülmektedir. Bu ortalamaların etkisini incelemek için ANOVA sonuçlarını incelediğimizde ise öğrencilerin yaşlarına göre iyi oluş puanlarında istatistiki olarak anlamlı bir şekilde farklılaşmadığı saptanmıştır, $F(3,104)=1.89, p=.10, \eta^{2}=.085$. (levene $\left.=.37\right)$

Ebeveyni evli ergenlerin iyi oluş düzeylerinde yetişmiş olduğu ebeveyn eğitim tutumune göre anlamlı biçimde farklılaşıp farklılaşmadığ 1 incelenmek istenmiş, bu analize göre yetişmiş olduğu ebeveyn eğitim tutumune ilişkin ortalamalar ile standart sapmaları belirlenmiş ve tek yönlü varyans analizi (ANOVA) gerçekleşirmiştir. Ebeveyni evli ergenlerin iyi oluş düzeylerinin yetişmiş olduğu ebeveyn eğitim tutumune göre değişimi incelendiğinde ihmalkar olan ebeveynlerin çocuklarının iyi oluş puanlarının $(\mathrm{M}=60.66, \mathrm{SD}=$ 18.14) demokratik $(M=70.75, S D=111.76)$, otoriter $(M=69.72, S D=15.76)$ ve aşırı koruyuculardan $(\mathrm{M}=64.50, \mathrm{SD}=17.92)$ düşük olduğu görülmektedir. $\mathrm{Bu}$ ortalamaların etkisini incelemek için ANOVA sonuçlarını incelediğimizde iyi oluş puanlarında istatistiki olarak da anlamlı bir şekilde farklılaşmadığı saptanmıştır, $F(3,103)=0.88, p=.45, \eta^{2}=.02$. (levene= .14)

İyi oluş düzeyleri için öğrencinin günlük internet kullanımına göre değişip değişmediği analiz edilmiştir. Günlük internet kullanımına ilişkin ortalamalar ile standart sapmalar belirlenmiş ve varyans analizi (ANOVA) gerçekleştirilmiştir. Sonuçlara göre özellikle 5 saat ve üzeri internet kullanan öğrencilerin ortalamalarının $(\mathrm{M}=63.76, \mathrm{SD}=16.30) \quad$ diğerlerinden daha düşük olduğu göze çarpmaktadır. 1 saat kullananların $(\mathrm{M}=74.61, \mathrm{SD}=13.14) \quad$ ve 2 saat kullananların $(\mathrm{M}=74.11, \mathrm{SD}=12.56)$ da en yüksek iyi oluş puanlarına sahip oldukları görülmektedir. ANOVA sonuçlarına göre günlük internet kullanımının kullanılan saate göre anlamlı olmadığı tespit edilmiştir $(\mathrm{F}(5,103)=$ 2.14, $\mathrm{p}=0.07, \eta^{2}=0.9$ (levene $\left.=.21\right)$ 


\section{Ebeveyni evli ergenlerin İnternet bağımlılı̆̆ düzeylerinin Cinsiyet, Öğrenim Gördü̈̆̈̈ Okul Türü, Yaş, Yetiştiği Eğitim Stili, Sosyoekonomik Duruma ve Günlük İnternet Kullanımına Göre İncelenmesine İlişkin Bulgular}

Araştırmada ebeveyni evli ergenlerin internet bağımlılı̆̆ı düzeylerinde erkek ile kızlar arasında anlamlı farkın olup olmadığı incelenmek istenmiş ve bu analize ilişkin bağımsız örneklem $t$ testi analizi gerçekleştirilmiştir. Ebeveyni evli ergenlerin internet bağımlılığı düzeyleri puan ortalamaları incelendiğinde, erkekler $(M=29.33, S D=9.68)$ ve kızlar $(M=28.24, S D=10.39)$ arasında önemli bir farklılık görülmemektedir. Puan ortalamaları arasında yapılan $t$ testi sonuçlarına göre de istatistiki olarak anlamlı bir fark bulunamamıştır, $\mathrm{t}$ $(107)=0.53, \mathrm{p}=0.59$ (levene $=.14$ ). Bu sonuçlara göre ebeveyni evli ergenlerin internet bağımlılı̆̆ düzeylerinde erkek ve kızların birbirlerine benzer oldukları ifade edilebilir.

Araştırmada ebeveyni evli ergenlerin internet bağımlılığı düzeylerinde okul türleri arasında anlamlı farkın olup olmadığı incelenmek istenmiş ve bu analize ilişkin bağımsız örneklem t testi gerçekleştirilmiştir. Ebeveyni evli ergenlerin internet bağımlılı̆̆ düzeyleri puan ortalamaları okul türüne göre incelendiğinde; mesleki ve teknik lisede okuyanların puanlarının $(M=29.58$, $\mathrm{SD}=10.40)$ anadolu lisesinde okuyanlara $(\mathrm{M}=28.21, \mathrm{SD}=8.82)$ oranla görece yüksek olduğu görülmektedir. Ancak, bu puanlar ortalamaları arasında yapılan $\mathrm{t}$ testi sonuçlarına göre istatistiki olarak anlamlı bir fark bulunamamıştır, $t_{(107)}=-0.65, p=0.52$ (levene $=.24$ ). Bu sonuçlara göre ebeveyni evli ergenlerin internet bağımlılı̆̆ı düzeylerinde okul türüne göre birbirlerine benzer oldukları ifade edilebilir.

Ebeveyni evli ergenlerin internet bağımlılı̆̆ı düzeylerinde yaşlarına göre anlamlı biçimde farklılaşıp farklılaşmadığ incelenmek istenmiş, bu analize ilişkin ortalamalar ile standart sapmaları belirlenmiş ve tek yönlü varyans analizi (ANOVA) gerçekleştirilmiştir. Ebeveyni evli ergenlerin internet bağımlılığı düzeylerinin yaşa göre değişimi incelendiğinde 17 yaşındaki ergenlerde internet bağımlılığı puanlarını $(\mathrm{M}=31, \mathrm{SD}=11.01)$ diğer yaş gruplarına göre görece yüksek olduğu 14 yaşında olanlarda ise $(M=26.58, S D=7.27)$ en düşük olduğu görülmektedir. Bu ortalamaların etkisini incelemek için ANOVA sonuçlarını incelediğimizde ise öğrencilerin yaşlarına göre internet bağımlılığı puanlarında istatistiki olarak anlamlı bir şekilde farklılaşmadığ saptanmıştır, $F(5,102)=1.43, p=.21, \eta^{2}=.066$ (levene $\left.=.21\right)$. 
Ebeveyni evli ergenlerin İnternet bağımlılığı düzeylerinde yetişmiş olduğu ebeveyn eğitim tutumune göre anlamlı biçimde farklılaşıp farklılaşmadığı incelenmek istenmiş, bu analize göre yetişmiş olduğu ebeveyn eğitim tutumune ilişkin ortalamalar ile standart sapmaları belirlenmiş ve tek yönlü varyans analizi (ANOVA) gerçekleştirilmiştir. Ebeveyni evli ergenlerin internet bağımlılığı düzeylerinin yetişmiş olduğu ebeveyn eğitim tutumune göre değişimi incelendiğinde ihmalkâr olan ebeveynlerin çocuklarının internet bağımlılığı puanlarının $(\mathrm{M}=27.66, \mathrm{SD}=12.50)$ demokratik $(\mathrm{M}=28.16 .72$, $\mathrm{SD}=8.45)$, otoriter $(\mathrm{M}=28.37, \mathrm{SD}=9.68)$ olanlardan düşük olduğu aşırı koruyucuların ise en yüksek olduğu $(\mathrm{M}=32.50, \mathrm{SD}=11.96)$ görülmektedir. Diğer gruplar arasında ise göze çarpan bir fark görülmemektedir. Bu ortalamaların etkisini incelemek için ANOVA sonuçlarını incelediğimizde internet bağımlılı̆̆ı puanlarında istatistiki olarak da anlamlı bir şekilde farklılaşmadığı saptanmiştır, $F(3,103)=0.52, p=.66, \eta^{2}=.015$ (levene $=.68$ ).

Ebeveyni evli ergenlerin internet bağımlılı̆̆ düzeylerinde sosyoekonomik duruma göre anlamlı biçimde farklılaşıp farklılaşmadı̆̆ incelenmek istenmiş, sosyoekonomik duruma ilişkin ortalamalar ile standart sapmaları belirlenmiş ve tek yönlü varyans analizi (ANOVA) gerçekleştirilmiştir. Ebeveyni evli ergenlerin internet bağımlılığı düzeylerinin sosyoekonomik duruma göre değişimi incelendiğinde orta sosyoekonomik duruma sahip ergenlerin internet bağımlılığı puanlarının $(\mathrm{M}=32.11, \mathrm{SD}=912.05)$ düşük $(\mathrm{M}=$ $28.21, \mathrm{SD}=8.90$ ) ve yüksek olan gruptan yüksek olduğu tespit edilmiştir. ANOVA sonuçlarını incelediğimizde ise öğrencilerin sosyoekonomik duruma göre internet bağımlılığı puanlarında istatistiki olarak anlamlı bir şekilde farklılaşmadığ saptanmıştır, $F(2,106)=0.78, p=.46, \eta^{2}=.015$. (levene $=.27$ ).

İnternet bağımlılığı düzeyleri için öğrencinin günlük internet kullanımına göre değişip değişmediği analiz edilmiştir. Günlük internet kullanımına ilişkin ortalamalar ile standart sapmalar ve varyans analizi (ANOVA) sonuçları tablo 20'de verilmiştir. Tabloda görüleceği üzere özellikle 5 saat ve üzeri internet kullanan öğrencilerin ortalamalarının diğerlerinden daha yüksek olduğu göze çarpmaktadır. 1 saat kullananların da en düşük internet bağıml-lığı puanlarına sahip oldukları görülmektedir. ANOVA sonuçlarına göre günlük internet kullanımının anlamlı olduğu tespit edilmiştir $\left(\mathrm{F}_{(5,103)}=6.56, \mathrm{p}\right.$ $\left.=0.001, \eta^{2}=0.24\right)$. Bu etkinin büyük düzeyde etki büyüklüğüne sahip olduğu görülmüştür. Anlamlı çıkan sonucun hangi gruplar arasında olduğunu belirlemek için Tukey testi yapılmıştır. Post hoc analizi sonuçlarına 5 saat ve üstü 
internet kullanan öğrencilerin internet bağımlılıkları 1 saat kullananlara $(\mathrm{p}=.001)$ ve 2 saat kullananlara $(\mathrm{p}=.001)$ göre anlamlı bir şekilde daha yüksektir. Yine benzer şekilde 4 saat internet kullanan bireylerin internet bağıml1lıkları 1 saat kullananlara göre daha yüksektir $(\mathrm{p}=.05)$. Yine 3 saat kullananlarda da 1 saat kullananlara göre anlamlı bir şekilde daha yüksektir ( $\mathrm{p}=.009)$. Sonuç olarak ebeveyni evli ergenlerde internet kullanma süresi 5 saat ve üzerine yaklaştıkça internet bağımlılığı artmakta, yüksek saatlerde internet kullanımı internet bağımlılığını artırmaktadır.

Tablo 20. Ebeveyni evli ergenlerin internet bağımlılı̆̆ı puanlan için günlïk internet kullanımına göre gruplar arası karşılaştırmalara ilişkin ANOVA tablosu (levene $=.84$ )

\begin{tabular}{llllllllllll}
\hline $\begin{array}{l}\text { Günlük inter- } \\
\text { net kullanımı }\end{array}$ & Mean & SD & N & Source & $\begin{array}{l}\text { Sum of } \\
\text { Squares }\end{array}$ & df & $\begin{array}{l}\text { Mean } \\
\text { Square }\end{array}$ & F & p & $\eta^{2}$ \\
\hline Hiç & 33 & 4.3 & 3 & $\begin{array}{l}\text { Gruplar } \\
\text { arası }\end{array}$ & 2.192 & 5 & 438.4 & 6.56 & .001 & 0.24 \\
1 Saat & 22.23 & 5.8 & 21 & & & & & & & \\
2 Saat & 25.81 & 6.8 & 27 & & & & & & & \\
3 Saat & 30 & 9.2 & 35 & & & & & & & \\
4 Saat & 31.30 & 7.4 & 10 & & & & & & & \\
5+ Saat & 37.07 & 11.3 & 13 & & & & & & & \\
\hline
\end{tabular}

\section{Tartışma Sonuç Öneriler}

Çalışmada ergenlerin iyi oluş özelliklerinin ebeveyni boşanmış ve ebeveyni evli ergenlere göre incelenmiş, iyi oluş düzeyi ebeveyninin boşanmış veya evli olmasına göre bir değişiklik göstermediği sonucu elde edilmiştir. Ebeveyni boşanmış ergenlerin yetişmiş olduğu ebeveyn eğitim tutumune bakıldığında demokratik, otoriter yada aşırı koruyucu ailede yetişen ergenlerin ihmalkâr ailede yetişen ergenlerden daha yüksek olduğu sonucu elde edilmiştir. Sonuç olarak ihmalkâr ailelerde yetişen ergenlerin iyi oluş düzeyleri diğer eğitim stillerinde yetişenlere göre daha düşüktür. Özellikle ergen çocukları olan boşanmış bireyler boşanma sonrası ergen çocuklarının kendilerini toparlayabilmeleri için onlara yardım etmeleri gerekmektedir. Tas (2017), (2018), boşanma sonrası süreçte ebeveynlerin çocuğa/ergene karşı duruşu ile vereceği desteğin düzeyine göre çocukların/ergenlerin hangi derecede olumlu/olumsuz etkilendiklerini belirlemektedir. Demokratik ailede yetişen ergenler, ebeveynleri ile zaman geçirebilen bireylerdir. 
Önemsenmesi gereken başka bir alan ergenlerin iyi oluş düzeylerinin ebeveyn eğitim tutumu ile ilişkili olmasıdır. Yukarıda çalışma sonucunda görüldüğü gibi demokratik ebeveyn eğitim tutumunde yetişen ergenlerin iyi oluşlarının otoriter ebeveyn eğitim tutumundeki ergenlere nazaran daha iyi olduğu, otoriter ebeveyn eğitim tutumunde yetişen ergenlerin ise ihmalkar ebeveyn eğitim tutumunde yetişenlere nazaran iyi oluş seviyelerinin daha yüksek olduğu bulgusu elde edilmiştir. Bu sonuçlara göre otoriter de olsa ergenlerin ebeveynleri tarafından muhatap alınmasının iyi oluşlarını az da olsa etkilediği görülmektedir. En kötü durum ise ebebeynler tarafından ihmal edilen ergenler olarak açıklanabilir.

Yapılan çalışmada elde edilen diğer bulgulara baktığımızda, aile ile boş zaman geçirme öznel iyi oluş durumunu etkilemektedir. Sarriera ve arkadaşları (2013) boş zamanlarında aileyle birlikte vakit geçirmesinin ve yakın olmanın ergenlerde öznel iyi oluşu önemli ölçüde etkilediğini belirtmektedir. İhmalkâr ailede yetişen ergenlerin genelde aileleri ile zaman geçirme durumları olmamaktadır. Sosyoekonomik durumun iyi oluş düzeyleri ile ilişkisi incelendiğinde ise sosyoekonomik duruma göre iyi oluş puanlarında istatistiki olarak anlamlı bir fark olmadığı saptanmıştır. İyi oluş düzeyleri ile öğrencinin günlük internet kullanımı arasındaki ilişkiye bakıldığında iyi oluş düzeyinin günlük kullanılan internet süresinden etkilenmediği tespit edilmiştir. İnternet bağımlılığı düzeylerinin öğrencinin günlük internet kullanımına göre değişip değişmediği incelendiğinde internet kullanma süresi 5 saat ve üzerine yaklaştıkça internet bağımlılığı artmaktadır. Yani yüksek saatlerde internet kullanımı internet bağımlılığını artırmaktadır. Boşanmamış ailelerdeki ergenlerin iyi oluş düzeylerinin öğrencinin günlük internet kullanımına göre değişip değişmediğine bakıldığında, günlük internet kullanım süresi arttıkça ergenlerin iyi oluş düzeyleri azalmaktadır.

Genel olarak bakıldığında internette harcanan sürenin fazlalığının bağımlılık yapmakla ilişkili olduğu sonucu elde edilmiştir. Ergenler genellikle kendilerini iyi hissetmediklerinde internette zaman harcayabilmektedirler. Ergenlerin internette çok fazla zaman geçirmeleri sonucunda ise daha az hareketlilik ve sosyal hayatta kendisini geri çekme durumu ortaya çıkmaktadır. Kendilerini iyi hissetmeyen veya duygusal problemleri ile başa çıamayan ergenlerde internette zaman harcamayı tercih edebilmektedir. Bu sonucu destekleyen çalışmalar da bulunmaktadır (Derin ve Bilge, 2016; Çiğdem ve Yarar, 2015). 
Ebeveynleri evli ergenlerin internet bağımlılığı düzeylerinin öğrencinin günlük internet kullanımına göre değişip değişmediği incelendiğinde, ebeveyni evli ergenlerde internet kullanma süresi 5 saat ve üzerine yaklaştıkça internet bağımlılığı artmakta, yüksek sürelerde internet kullanımı internet bağımlılı̆̆ını artırmaktadır. Tas (2019)'ın benzer bir çalışmasına göre oyun bağımlılığında 5 saat ve üzeri internet kullanan genel ergen grubunun oyun bağımlılığı puanları sırasıyla 1,2,3,4 saat kullananlara göre anlamlı bir şekilde daha yüksek olduğu sonucu elde edilmiştir. Bu doğrultuda çok fazla internet kullanımının oyun bağımlılığı ile ilişkili olduğu söylenilebilir.

Schmidt-Denter ve Beelmann (1995), bireyler, çocuklar ve ergenler ile uzun süre yapmış olduğu boşanma yardım grup danışmanlığında, bu danışmanlığın bireyler üzerinde oldukça olumlu sonuçlar doğurduğunu, özellikle boşanma sonrası yeni sürece adapte olma ve topluma entegre olma alanlarında başarıya ulaşıldığını belirtmektedir. Bu bağlamda ergen yardım grupları problemlerin çözümlenmesinde yardımcı olabilmektedir. İnternet bağımlılı̆̆ı olan ergenlerin de yukarıda belirtilen yardım gruplarından problemleri ile ilişkili yardım almaları internet bağımlılıklarını azaltabilir ve kendi iyi oluşlarına katkı sağlayacabilir. Bu sayede ergenlerin saatlerce internet başında zamanlarını geçirmeleri yerine sosyalleşmelerine yardımcı olunabilir. Ayrıca okullarda psikolojik danışmanlar tarafından öğrencilere pozitif psikoloji alanında yapılacak çalışmaların iyi oluşu artırarak dolaylı yoldan internet bağımlılığını azaltabileceği düşünülmektedir. Anne-babalara ise teknolojinin bilinçli kullanımı, anne-baba tutumları, aile içi iletişim ve pozitif disiplin konularında bilinçlendirme çalışmalarının yapılmasının ergenler üzerinde pozitif bir etki oluşturacağı düşünülmektedir. 


\title{
EXTENDED ABSTRACT
}

\section{Five Dimensional Well-Being Model of Adolescents with Divorced and Non-Divorced Parents and Examination of Internet Addiction Levels}

\author{
Besra Taş - Sedat Ateş \\ Sabahattin Zaim University
}

The aim of this study is to determine whether there is a relationship or not between five-dimensional well-being model and internet addiction levels in adolescents with divorced and married parents.

In this research, we are trying to answer to the questions below :

1. Is there a significant difference between the Five-Dimensional WellBeing Model and Internet Addiction Levels of adolescents whose parents are divorced and non-divorced?

2. Five-Dimensional Well-Being Model and Internet Addiction Levels of Adolescents with divorced and non-divorced parents; Does it differ significantly according to gender, marital status of parents, age, daily internet use, the type of school where they are studying, the economic situation in which they live now and the parent's attitude of education?

It is seen in the literature review that there are very different results.

It is stated that especially internet usage times increase internet addiction (Demirli and Arslan, 2018; Günüç, 2013; Tas, 2019).

Gender, socioeconomic level, purpose of internet use, parental attitudes, spending quality time with adolescents, ease of access to the internet are also important factors that affect internet addiction

When the studies on well-being in the literature are analyzed, it is seen in most studies that there is a negative relationship between the well-being of adolescents and internet addiction (Çiğdem and Yarar, 2015; Derin and Bilge, 2016; Sharma and Sharma, 2018; Wang et al., 2013; Head , Soysal and Aysan, 2016).

The divorce status of the parents also affects adolescent individuals necessarily. 
Some studies state that this process is a process that needs help for parents and adolescents (Wallerstein and Blakeslee, 1989; Dreikurs, 1968; Fthenakıs, Niesel and Kunze: 1982).

Tas (2017), (2018) states that parents' attitude and support to adolescents are also important after the divorce process.

Methodology

The group of the research consists of 211 students with 102 divorced and 109 non-divorced families studying in high school students in the 2018-2019 academic year in Istanbul.

The average age of the participants was 15.5, the standard deviation was $1.2,74$ of the participants were male and 137 were female.

This research is a relational study in the screening model.

Quantitative data collection methods were used in the study.

Internet addiction and well-being levels of high school students whose parents live together and divorced were examined according to various demographic variables

EPOCH (Five Dimensional Well Being) Scale, developed by Kern, Benson, Steinberg and Steinberg (2016) and adapted to Turkish by Demirci and Ekşi (2015) in addition to demographic data in the research. Converted into short form by Pawlikowski et al. (2013) developed by Young (1998) and Young Internet Addiction Test Short Form (YIBT-KF), adapted in Turkish by Kutlu et al. (2016), was used.

Variance analysis (ANOVA) and $t$ test were used in the analysis.

As the parametric analyzes is used, the distributions of the variables were examined, and the skewness and kurtosis values were found to be good (0.40.03 ) and internet dependence (0.5-0.02), and it was concluded that the distribution was normal.

Whether the variances are matched for variance analysis was checked by levene test and it was seen that variances were equal for all analyzes.

Results and Conclusions

According to the results of the research, well-being characteristics of adolescents examined between divorced and non-divorced parents. It was concluded that the level of well-being did not change according to whether her parents were divorced or married.

Considering the parental education attitude raised by adolescents whose parents are divorced. 
It was concluded that the adolescents raised in the democratic, authoritarian and overprotective family were higher than the adolescents raised in the negligent family.

As a result, it was concluded that the well-being levels of adolescents raised in negligent families were lower than those raised in other educational attitudes.

When internet addiction scores are examined, it is seen that adolescents whose parents are divorced have a slightly higher average compared to married adolescents, but this difference is not statistically significant.

As a result, the level of internet addiction does not differ depending on whether parents are divorced or non-divorced

According to the results of the study, the finding that internet addiction increases when the internet usage time is 5 hours or more in both groups of adolescents.

Also, it has been concluded that high internet usage increases internet addiction.

There are some suggestions for reducing adolescents' internet addiction, preventing them and increasing their well-being.

Establishing adolescent help groups for adolescents who have difficulties after divorce can help in solving problems. In addition adolescents with Internet addiction getting help from their help groups related to their problems can reduce their internet addiction and contribute to their own well-being.

In this way, adolescents can be helped to socialize instead of spending their time on the internet for hours.In addition, it is thought that the studies to be done by the psychological counselors in the field of positive psychology to the students can increase the well-being and indirectly reduce the internet addiction.

On the other hand, it is thought that awareness raising activities on conscious use of technology, parenting attitudes, family communication and positive discipline will have a positive effect on adolescents

\section{Kaynakça / References}

Baş, A. U., Soysal, F., ve Aysan, F. (2016). Üniversite öğrencilerinde problemli internet kullanımının psikolojik iyi-oluş ve sosyal destek ile ilişkisi. Itobiad: Journal of the Human \& Social Science Researches, 5(4). 
Creswell, J. W. (2012). Educational research: Planning, conducting, and evaluating quantitative and qualitative research. Boston, USA: Pearson.

Çevik, U. P. D. G. B., ve Çelikkaleli, Ö. (2010). Ergenlerin arkadaş bağlılığı ve internet bağımlılığının cinsiyet ebeveyn tutumu ve anne baba eğitim düzeylerine göre incelenmesi. Çukurova Üniversitesi Sosyal Bilimler Enstitüsü Dergisi, 19(3).

Çiğdem, H., ve Yarar, G. (2015). Meslek Yüksekokulu öğrencilerinin internet bağımlılıkları ile iyilik halleri arasındaki ilişkinin incelenmesi. Ejovoc (Electronic Journal of Vocational Colleges), 5(1), 72-81.

Demirci, İ., ve Ekşi, F. (2015). Ergenler için beş boyutlu iyi oluş modeli: EPOCH Ölçeği'nin Türkçe formunun geçerliği ve güvenirliği. Gençlik Araştırmaları Dergisi, 3(3), 9-30.

Demirli, C., ve Arslan, G. (2018). Ergenlerin internet bağımlılığı düzeylerinin incelenmesi. Istanbul Ticaret Üniversitesi Sosyal Bilimler Dergisi, 17(33), 49-64.

Derin, S., ve Bilge, F. (2016). Ergenlerde internet bağımlılı̆̆ ve öznel iyi oluş düzeyi. Türk Psikolojik Damışma ve Rehberlik Dergisi, 6(46).

Dreikurs, R. (1968). Die Ehe - eine Herausforderung. Ernst Klett Verlag: Stuttgart.

Fthenakis, W.E., Niesel, R. ve Kunze, H.R: (1982). Ehescheidung. Konsequenzen für Eltern und Kinder. Urban \& Schwarzenberg Verlag: München, Wien, Baltimore, 1982.

Göldağ, B. (2017). Ortaöğretim kurumlarında öğrenim gören öğrencilerin internet bağımlılık düzeyleri ile sürekli kaygı düzeyleri arasındaki ilişkinin incelenmesi. Turkish Studies, 12(11), 71-94.

Gross, E. F., Juvonen, J., ve Gable, S. L. (2002). Internet use and well-being in adolescence. Journal of social issues, 58(1), 75-90.

Günüç, S. (2013). Internet bagimliligini yordayan bazi degiskenlerin cart ve chaid analizleri ile incelenmesi. Türk Psikoloji Dergisi, 28(71), 88.

Kayri, M., ve Günüç, S. (2016). Yüksek ve düşük sosyoekonomik koşullara sahip öğrencilerin internet bağımlılığı açısından karşılaştırmalı olarak incelenmesi. The Turkish Journal on Addictions, 3(2), 165-183.

Kern, M. L., Benson, L., Steinberg, E. A., ve Steinberg, L. (2016). The EPOCH measure of adolescent well-being. Psychological assessment, 28(5), 586.

Kutlu, M., Savc1, M., Demir, Y., ve Aysan, F. (2016). Young internet bağımlılı̆̆ı testi kısa formunun Türkçe uyarlaması: Üniversite öğrencileri ve ergenlerde geçerlilik ve güvenilirlik çalışması. Anadolu Psikiyatri Dergisi, 17(1), 69-76. 
Pawlikowski, M., Altstötter-Gleich, C., ve Brand, M. (2013). Validation and psychometric properties of a short version of Young's Internet Addiction Test. Computers in Human Behavior, 29(3), 1212-1223.

Sagone, E., ve De Caroli, M. E. (2014). Relationships between psychological wellbeing and resilience in middle and late adolescents. Procedia-Social and Behavioral Sciences, 141, 881-887.

Sarriera, J. C., Paradiso, A. C., Abs, D., Soares, D. H. P., Silva, C. L., ve Fiuza, P. J. (2013). The well-being of adolescents trough their leisure time. Estudos de Psicologia (Natal), 18(2), 285-295.

Streit. W., (2014). Wilde Jahre- gelassen und positiv durch die Pubertat. Ein Letfaden für Eltern. Kreuz Verlag.

Schmidt-Denter, U. ve Beelmann, W. (1995). Familiäre Beziehungen nach Tren- nung und Scheidung: Veränderungsprozesse bei Müttern, Vätern und Kindern. Forschungsbericht. Band 1: Textteil. Universität Köln.

Sezer, F. (2011). Ortaöğretim öğrencilerinin öznel iyi oluş durumlarının bazı değişkenler açısından incelenmesi. Milli Ĕ̆itim Dergisi, 41(192), 74-85.

Sharma, A., ve Sharma, R. (2018). Internet addiction and psychological well-being among college students: A cross-sectional study from Central India. Journal of family medicine and primary care, 7(1), 147

Söner, O. ve Yılmaz, O. (2018). Lise öğrencilerinin sosyal medya bağımlılı̆̆ı ve psikolojik iyi oluş düzeyleri arasındaki ilişki. Ufuk Üniversitesi Sosyal Bilimler Enstitüsü Dergisi, 13, 61-76.

Tas, B. (2017). Researches on science and art in 21st century Turkey. Gece Kitaplığı. ISBN 978-605-180-771-3

Tas, B. (2018). Academic studies in educational sciences. Gece Kitaplığı. ISBN 978-605288-605-2

Tas, B., (2019). School attachment and video game addiction of adolescents with divorced vs. married parents. TOJET: The Turkish Online Journal of Educational Technology, 18(2), 93-106.

Wallerstein, J. ve Blakeslee, S. (1989). Gewinner und verlierer. Frauen, männer, kinder nach der scheidung. eine langzeitstudie. Aus den Amerikani- schen von Ute Mäurer und Andrea Galler. Droemer Knaur: München.

Wang, L., Luo, J., Bai, Y., Kong, J., Luo, J., Gao, W., ve Sun, X. (2013). Internet addiction of adolescents in China: Prevalence, predictors, and association with well-being. Addiction Research \& Theory, 21(1), 62-69.

Young, K. S. (1998). Caught in the net: How to recognize the signs of internet addiction-and a winning strategy for recovery. John Wiley \& Sons. 
Yu, L., ve Shek, D. T. L. (2018). Testing longitudinal relationships between Internet addiction and well-being in Hong Kong adolescents: cross-lagged analyses based on three waves of data. Child indicators research, 11(5), 1545-1562.

\section{Kaynakça Bilgisi / Citation Information}

Taş, B. ve Ateş, S. (2020). Boşanmış ve evli ebeveynlere sahip ergenlerin beş boyutlu iyi oluş modeli ve internet bağımlılık düzeylerinin incelenmesi. OPUS-Uluslararası Toplum Araştırmaları Dergisi, 15(25), 3198-3232. DOI: 10.26466/opus.650135 